А. А. Свириденко

\title{
РУССКИЙ ЯЗЫК КАК ФОРМА ПРОЯВЛЕНИЯ НАЦИОНАЛЬНОГО БЫТИЯ
}

(Философская концептуализация) 


\section{А. А. Свириденко \\ Автор выражает благодарность Ф. Ирзабекову за книгу «Тайна русского слова».}




\section{ВВЕДЕНИЕ}

Данное исследование носит философсколингвистический характер. Исследование языка в философском смысле отличается от его лингвистического анализа, но взаимосвязано с ним. Философия осмысливает язык сквозь призму проявления бытия языка и бытия его носителей. Обращение философов к языку как к объекту исследования имеет довольно глубокие исторические корни. Об этом свидетельствуют наблюдения античных философов и философов Средневековья. Между тем, философское осмысление языка имеет свою специфику.

По мнению В.В. Бибихина, философы, благодаря которым мы знаем, что такое философия, никогда отдельно не ставили вопрос о языке. Осмысление имени слова всегда переходило на сами вещи, и, с другой стороны, когда они говорили «Язык», они не огораживали себя предметом, который описан в учебниках по языкознанию - через язык жестов, язык молчания и язык природы они быстро переходили опять же к самим вещам, к миру. Как Платон, заводя речь об "элементах" слова, думает о стихиях, из которых, словно огромная 
прекрасная речь, соткан мир [4. 5]. В дальнейшем философия языка совершает лингвистический поворот в работах Людвига Витгенштейна - - представителя западноевропейской философии XX века.

В данном случае объект и процесс, а также условия его бытия, тесно взаимосвязаны. 


\section{ГЛАВА І. РУССКИЙ ЯЗЫК КАК ЧАСТЬ МИРОВОЙ}

КУЛЬТУРЫ.

Говоря о языке, в данном случае русском, как о форме самопроявления, необходимо провести глубокий анализ и осмысление антологических корней этого процесса. Бытие есть способность объекта (факта, явления) быть, существовать. В то же время самовыражение объекта, его проявление можно определить термином «бытийствование». Примером сему может служить личность артиста и его роль. Например, жизнь артиста Фёдора Ивановича Шаляпина есть его бытие, а исполнение им роли Ивана Грозного в опере - суть форма самопроявления объекта, то есть бытийствование.

В данном случае объект и процесс, а также условия его бытия тесно взаимосвязаны. Это выражается в языковой характеристике осмысления времени и пространства. Красной нитью это проходит в пословицах и поговорках, в художественной литературе, в живописи, в музыке и т.п. Таким образом, геополитическая среда оказывает влияние на ментальность народа, которая наиболее характерно выражается в языковых конструкциях. Такие 
пословицы как: «За семь вёрст киселя хлебать», «Обещанного три года ждут» свидетельствуют о наличии расстояний большой протяжённости, что затрудняет процесс исполнения представленных задач во времени. Специфика российских пространств приводила к тому, что чиновник, назначенный на должность, мог прибыть из Петербурга к месту назначения, скажем в Подольск, только через три года. Переждал морозы, переждал разлива рек, осеннюю и весеннюю распутицу, и к моменту его прибытия к месту назначения сменялись губернаторы и даже цари, что меняло смысл ранее поставленной задачи. Это нашло выражение и в литературе, и в песенной культуре.

Кстати, ни в одной из европейских стран не воспевается (не уделяется столько внимания) песням ямщика и его далёким переездам, поскольку эти явления не характерны для европейских стран. И романтические песни гондольера в Венеции не идут ни в какое сравнение с грустными песнями ямщика, в которых слышится «что-то родное». Давайте сравним два четверостишия: 
Прозрачен воздух чернеет,

И Рейн уснул во мгле.

Последним лучом пламенеет

Закат на прибрежной скале.

\section{(Г.Гейне);}

Встает заря во мгле холодной, На нивах шум работ умолк.

С своей волчихою голодной Выходит на дорогу волк...

(А.С.Пушкин);

Улавливаете разницу? В первом четверостишии чувствуется спокойная умиротворённость, эстетика созерцания. И даже мгла ассоциируется со спокойными летними сумерками. Прибрежная скала, облитая закатом или багрянцем заката не вызывает никаких отрицательных эмоций. Да и о бродящих по дорогам волках в Европе и в Германии, в частности, ко времени написания этих 
стихотворений стали как-то забывать. А что же у нас? У нас мгла холодная. Иными словами, беспросветная, жуткая. Седой туман разлился над местностью, земля, припорошенная снежком, уже звенит от мороза. Как говорят, зуб на зуб не попадает... А тут ещё волк, да не один, а с подружкой. Поэтому и чувствуется здесь тревога, страх, неопределённость, что свойственно русским как в далёком прошлом, так и сегодня в условиях возрастания рискогенности общества.

Влияние геополитической среды на личность и её речевые конструкции здесь, как говорят, налицо. И таких примеров можно привести множество.

Язык, как социокультурное явление, испытывает на себе влияние внешней среды (других языков) и, в свою очередь, оказывает на эту среду (другие языки) обратное влияние. Причём влияние это может носить нейтральный, позитивный и негативный характер. Реалии сегодняшнего дня свидетельствуют о необходимости популяризации русского языка, его сохранения и развития. Русский язык и отечественная школа сегодня достаточно злободневный 
вопрос. Говоря о русском языке как о форме бытия необходимо отметить, что ещё в глубокой древности было обращено внимание на первичность онтологических корней по отношению к процессу реализации языка. Слово, как основа языка, выделено в качестве первопричины его бытия ещё в Библейских текстах: «В начале было слово...» [5. 895]. Слово, глагол, вербальная форма - тот фундамент, в котором покоится величественное знание языка. Слово представляется здесь в качестве потенциального источника энергии величайшей силы, слово есть ипостась самого Создателя мира.

По мнению большинства историков, язык, появление членораздельной речи выступают в качестве предмета культуры как отдельных народов, так и всего человечества. Язык, являясь способом коммуникации, объединяет духовное богатство мира, которое атрибутивно присуще носителям того или иного языка. Язык отражает историческое развитие народа как носителя языка, в нашем случае, русского. Сегодня, в условиях доминирования информационных технологий, технократизации социокультурной сферы язык остаётся 
ключевым компонентом как внутрикультурной, так и межкультурной коммуникации. Слово, как уже было отмечено, является не только носителем информации, но и выступает как объект, обладающий определённой энергией. Конструкция русского языка представляет собой лингвокультурное и социокультурное поле, включающее в себя онтологированные формы народной ментальности [2. 6-11]. Язык, слово, речевая конструкция могут быть рассмотрены как ключ к духовному миропониманию. Достаточно чётко это прослеживается в текстах священного писания. В книге «Бытие» повествуется о слове как о предтече бытия (мироздания). Слово в этом контексте - как воплощение идеи, информационный источник бытия. Слово и его гносеологическое значение занимают срединное место между представлением образного знания и понятием, характеризующим абстрактное мышление [21. 286]. Слово, как первооснова языка, имеет смысл на общетеоретическом уровне процесса познания. Русский язык представляет собой сложную систему и выступает как результат интеллектуального творчества народа. История 
свидетельствует, что торговля, мореплавание, военные походы, завоевания лежат в основе взаимодействия культур, в том числе и языков. В данной работе автор ставит задачу проследить и раскрыть взаимосвязи с другими языками и культурами. Русский язык, как и другие языки, не может развиваться и функционировать автономно, он испытывает на себе влияние других языков и культур и, в свою очередь, оказывает влияние на мировую культуру. Хотя следует признать, что сегодня мировой языковой экономикой является английский язык, что отражается и на современных конструкциях русского языка. В то же время во многих странах имеются славянские университеты, многие студенты и специалисты изучают русский язык. Тем не менее, следует признать тот факт, что в последние годы русский язык всё более вытесняется английским. Прежде всего, это выражается в том, что сленг англоязычной этимологии сегодня достаточно глубоко проник в русский язык. Причём эта тенденция усиливается. Это вызывает определённую тревогу среди специалистов языкознания и носителей русского языка в целом. В отличие от 
традиционного

языка

американизмы и компьютерный сленг ведут, в конечном итоге, к потере формы передачи информации. Причём следует взвешенно анализировать происходящее и не ударяться из крайности в крайность. Бессмысленное засилье иностранных слов также опасно и нелепо, как и полный отказ от них. В тех случаях, когда в русском языке имеется аналог иностранному слову, конечно, целесообразнее применить русскую форму. Другое дело, когда аналог отсутствует и слово (или термин) прочно укоренилось в русскоязычной языковой конструкции. Например, слово «конфорка» допустимо заменить словом «горелка». Однако исключить из лексикона слово стул только потому, что оно имеет немецкую этимологию, представляется весьма сомнительным. Осознавая факт доминирования английского языка, следует понимать, что каждый язык должен сохранить свою самобытность и выступать в качестве носителя народного менталитета. Семантика языка, его многовековые традиции, дух должны бережно сохраняться [20. 176-177]. 
Вопросы языкознания, культуры и образования, их взаимоотношение и взаимовлияние имеют давнюю историю, но, тем не менее, эти вопросы актуальны и в наши дни. Язык, как зеркало и инструмент этнической культуры, выполняет двоякую функцию как отражения, так и созидания [8]. Языковая культура может быть представлена как высший атрибут человеческого бытия. Небрежное отношение к языку ведёт, в конечном итоге, к деградации общества. Ещё в период царствования Николая I адмирал А. С. Шишков, будучи президентом российской академии наук, отмечал: «Народ российский всегда крепок был языком и верою. Язык делал его единомысленным, вера - единосущным. Однако мы сейчас часто можем видеть, что язык свой упадает, потому предпочитается ему чужой» [22. 20-21]. Русская языковая культура - это тысячелетний пласт истории. В целях сохранения этой сокровищницы мировой культуры необходимо увеличить количество часов на преподавание русского языка и литературы в школах. Необходимо установить строгую корректуру в периодических изданиях, на радио и телевидении. Во всех ВУЗах, 
независимо от профиля, необходимо ввести изучение таких предметов как «Этика делового общения», «Русский язык и культура речи». Эти предметы должны быть обязательными для изучения, а не просто факультативными занятиями. Поскольку речевая культура студентов, да и выпускников высших учебных заведений оставляет желать много лучшего. Русский язык, русское слово несут в себе неисчерпаемое духовное и эстетическое богатство. Слово есть первооснова языка, его значение практически неоценимо. Тем более пагубное, небрежное отношение к слову. К сожалению, мы часто неуважительно относимся к слову, не знаем значение и этимологию слова, тем самым, обкрадываем себя. Вот простой пример: мы постоянно употребляем слово «человек». Казалось бы, здесь всё ясно. Но на вопрос «каково значение этого слова?» девять студентов (да и не только) пожмут плечами. Обратимся к словарю А. С. Шишкова «Славянорусский корнеслов». По материалам этого словаря находим ответ. Термин (понятие) «человек» своими корнями восходит к понятию «слово». И этим подчёркивается отличие человека от других живых существ. 
Первоначально оно имело значение «словек», то есть несущий слово, обладающий словом. Затем «уловек», «чловек» и, наконец, «человек». Согласно библейскому тексту, слово - имя самого Бога. Отсюда следует, что человек (словек) есть существо, созданное Богом и обладающее членораздельной речью [12. 17-18]. Или, к примеру, слово «образование». Сегодня это слово весьма популярно: и образовательные реформы, и рынок образования, и (что уже совсем дико) образовательные услуги. Даже те учреждения, которые ранее назывались образовательными, именуются

ныне учреждениями, оказывающими образовательные услуги. Нонсенс, господа! У слова «образование» весьма интересная составляющая. Ведь корень этого слова - образ, а образ есть икона - образ, святой лик. Отсюда логически вытекает, что задачами и целями образования выступает не передача информации или суммы знаний, а формирование в человеке образа, т.е. божественной сущности, совершенства. А отклонение от образа есть нечто иное, например, безобразие [13. 17-18]. Образование не может и не должно приносить прибыли. 
Рассматривать образование как один из видов бизнеса - по сути своей искажать, уродовать образование. И закрывать школу по мотивам нерентабельности - преступление. Нельзя переводить всё на денежный эквивалент.

Хотелось бы остановиться на некоторых примерах, показывающих взаимодействие русского языка с другими, в частности, тюркскими, которые, в свою очередь, впитали в себя многие положения (конструкции) священного писания. Так, во многих тюркских языках слово «человек» произносится как «адам» или «одам» (с ударением на первый слог), что отсылает нас к ветхозаветной истории: Адам - прародитель всего человечества. Слово «предатель» в тюркских языковых конструкциях, к примеру, в азербайджанском языке звучит как «хаин». Каин (хаин) - первый предатель, убивший родного брата. А что означает «раскаяние»? Осознание своих ошибок, отказ от схожести с образом Каина, расставание с ним. Характеризуя кого-либо, мы весьма часто говорим «неприкаянный». Значит человек, не находящий в себе силы расстаться с образом Каина. Мечущийся по судьбе, без цели, без Бога 
в душе. А такие слова, как «чужой», «не наш», звучат как «хам». В русском языке под хамом понимают невоспитанного, циничного человека. А кто такой хам? Один из сыновей Ноя. Вот прямое свидетельство того, что языки уходят своими корнями в Божественное слово. Любой язык тем или иным образом содержит информацию о Боге и божественном начале. Есть безбожные люди, зато безбожных языков не бывает. Таким образом, Авесту, Ветхий Завет можно рассматривать как языковую матрицу, а русский язык как составляющую мировой культуры. В современной литературе слово, и это весьма обоснованно, характеризуется как ключ к смыслу. Это специфическая языковая констатация общесемиотического

факта, свидетельствующего, что смысл создаётся и является человеку лишь через слово (символ, знак). Есть все основания согласиться с мнением А. Вежбицкой по этому поводу. Она, в частности, утверждает, что мы можем добраться до мысли только через слова, никто пока ещё не изобрёл другого способа [10. 293]. В свою очередь, смысл, по мнению Г. П. Щедровицкого, есть не что иное, как «общая 
соотнесённость и связь всех относящихся к ситуации явлений» [24. 562].

Смысл всегда выступает априори по отношению к значению, которое неситуационно принадлежит языку. В лингвокультурологии, в eё эмпирической части, концепт отождествляется с типовым прототипом (типовым представлением), подвергается психологическому воздействию. Исследование различных аспектов русского языка, как метатеоретического концепта, в философском ракурсе может способствовать успешному разрешению такой существенной проблематики, как фрагментарный инструментальный охват, языковый охват языковых явлений, без взаимного учёта достижений представителей различных ветвей научного знания и философских течений, зачастую стоящих на противоположных позициях. Философия языка призвана конструировать общие теории языка в рамках философии и философской логики. В 90-е годы XX века окончательно формируется лингвокультурология, имеющая своим предметом язык, культуру и их взаимодействие. Таким образом, язык, как форма бытия, 
выражает менталитет его носителей (народа). В философском понимании можно говорить о бытийственности трёх концептуальных подходов (концептов) в семантике русского языка. В первом подходе обнаруживаются лексические формы, значение которых составляет содержание национального языкового сознания. Это содержание, в свою очередь, формирует картину мира носителей языка, картину, которая аккумулирует в себе национальную (языковую) культуру.

Второй момент заключается в более узком понимании семантических образований, относимых к числу концептов языка. Так, например, концепция метафизического плана предполагает структуру концепта:

Душа - истина, вера, надежда, любовь, счастье. По сути своей, это ментальные сущности высокой или предельной степени абстрактности, они отсылают нас к духовным (идеальным) формам бытия, к духовным ценностям. Это положение хорошо просматривается в евангельских положениях:

«...И где сокровище ваше, там будет и сердце ваше...»; 
«...Доколе углебаеши богатство своё, аки пчела. Взыщи лучше Царствия небесного...».

Евангельский текст выступает здесь как языковая конструкция и в то же время носитель информации об Откровении свыше. Определяя тем самым приоритет духовных ценностей. Смысл в данном случае постигается через знак (символ), дающий возможность раскрыть образное, предметное содержание в целях выражения содержания абстрактного. Исходя из вышеизложенного, можно сформулировать определение концепта как единицы концептивного сознания, отправляющей к духовным ценностям высшего порядка. Данная единица обладает языковым содержанием (выражением) и обладает этнокультурной спецификой [3. 19]. Основным признаком здесь выступает принадлежность к идеальному, духовному. Следовательно, концепт может быть представлен как форма бытийствования языка как объекта философского и лингвокультурного исследования. Русский язык не является здесь исключением. Языковая единица формируется речью в пространстве сознания (психики) человека. Она, как конструкция, как форма проявления, носит 
субъективный характер. В тоже время изменения сознания индивида здесь явно недостаточно, поскольку для формирования такой языковой единицы, как концепт, необходимо наличие читателя или слушателя, иными словами, другого субъекта. Таким образом, языковый концепт, как структура, может охватывать как пространство бытия, так и группы людей и, в конечном итоге, всего человечества.

\section{ГЛАВА ІІ. САКРАЛЬНАЯ СОСТАВЛЯЮЩАЯ В ЯЗЫКОВЫХ КОНСТРУКЦИЯХ.}

В поле зрения философов язык находится практически всегда. Во всяком случае, в качестве философской проблемы он рассматривается представителями софистов и Платоном. Изучение языка в философии, в определённом смысле, загадочно и мистично и в тоже время сочетает в себе научное и рациональное. Весьма интересным представляется тот факт, что в старославянском языке понятие «язык» выступало не только в качестве инструмента речи, но и как «племя», «народ». То есть язык как таковой и его 
носитель по смыслу и объёму совпадали [11. 951, 849, 189]. Вопрос языка, как носителя культуры в истории человечества, имеет сакральный характер и впервые поднимается в духовной сфере. Самый древний текст, дошедший до нас, касающийся философского понимания языка, это мифический богословский трактат (Древний Египет). В этом трактате язык объявляется творческой созидательной силой. Бог Птаху свёл воедино слова и мысли и сотворённый этими силами мир. Письменность есть творение шумерсковавилонского Бога Набули - покровителя писцов, наук и писцов среди богов. Его символом (знаком) был писцовый грифель. Он также почитается как владелец таблиц судеб, определяющих движение мира и мировых событий. Владение таблицами предполагало власть над миром. Его супруга - богиня Нисаба покровительствовала сельскому хозяйству (земледелию). В дальнейшем она взяла под своё крыло числа, науку, архитектуру, астрономию и писцовое искусство. Её знаком (эмблемой) также стал писцовый грифель. Параллельно развивалась система языка и письменности в Древнем Египте. Эта система письменности 
использовалась с III тысячелетия до нашей эры до III-IV вв. нашей эры. Знаменитые египетские иероглифы. Слово иероглиф на самом деле возникает позже и имеет греческую этимологию hieros - священный, божественный и gly - вырезанный (выдавленный). Перевод слова иероглиф может обозначать как «вырезанный» и «священный», так и «священные вырезанные знаки». По мнению М. А. Коростовцева, иероглиф означает письмо или слово Бога [15.31]. Интерпретируя данный термин к русской языковой культуре, допустимо перевести иероглиф как «божественное откровение». По мнению древних египтян, письменность - это творение Бога Тота. Тот - всесведующий Бог, ночное божество Луны. Он по ночам заменяет Бога Солнца - Ра. Одновременно он (Тот) является сердцем и сановником $\mathrm{Pa}$, записывает его указания и распоряжения и запечатывает письма. Также Тот властвует над царством мёртвых. Он создатель языков и письменности. Его называют языком Бога Птаха. При внимательном сопоставлении имён Богов египетского пантеона с определёнными лингвистическими конструкциями русского 
языка можно выявить взаимопроникновение. Фундаментальных исследований по этому вопросу нет. Тем не менее можно предположить, что имя Бога Ра присутствует в корневой основе некоторых русских слов. Ра Бог Солнца, и эти слова связаны с Солнцем. Например, рассвет (Ра-ссвет - свет, данный Богом Ра), Радуга (ра-дуга солнечная, божественная), Рай (Рай - место обитания Бога), разум (Ра-зум - ум, данный Богом), радость (радость - дарованный $\mathrm{Pa}$ достаток, как материальный, так и духовный). Аналогом Тота в древней Греции можно считать Гермеса. Гермес - проводник душ умерших и основатель познания, изобретатель алфавита. Опять возникают ассоциации с русским языком. В православном богослужении в определённых случаях читается литургия Василия Великого, по окончании которой хор поёт: «Исполаэти деспота». Эта же фраза поётся, когда на службе присутствует архиерей. Что означают эти слова? Если перевести на русский язык, то получим: «Вечная слава тебе, Господин!» Господин (Господь). Деспот Господин. В русском разговорном языке принято под деспотом понимать жестокого 
правителя, отсюда - деспотизм. Когда мы читаем русские народные сказки или былины, то часто встречаемся с выражением: «Исполать тебе, добрый молодец!». «Исполать» как раз от греческого - исполаэти, то есть вечная слава. Согласно преданиям многих народов и священному писанию, человечество изъяснялось на одном языке. Однако когда люди дерзнули возвести башню до самого неба (Вавилонская башня), Бог смешал языки, и люди перестали понимать друг друга. Но поскольку все языки имеют один исток, в разных языках у народов, живущих за тысячи километров друг от друга, можно найти общие корни и языковые конструкции. Например, латинский «игнис», имя «Агния» и «огонь» находятся в явном родстве со скифским Богом Агни - Бог огня. Об этом хорошо говорит замечательный поэт Генрих Сапгир в своём стихотворении «Лингвистический сонет»:

«Ты, я, они - из одного зерна, Латинский игнис и огонь в родстве. Лингвист расскажет множество примеров.

Я вижу лоб священного слона, И на закате окна по Москве, 
Как отблеск на ногах легионеров...» Весьма интересно взаимоотношение русского языка с индийским, в частности, с древнеиндийским (санскрит). Древнеиндийские тексты «Веды» в переводе означают знание. А теперь возьмём слова из русского языка: «поведать», «отведать», «разведать», «выведать», «исповедь», «ведьма», «ведунья» везде корнем выступает «вед». В истории известны многие факты миграции народов. Так, на рубеже III-II тысячелетия до н.э. некоторые арийские племена мигрировали на север Индии, и ассимилировались с местным населением, осели там. Весь крупный рогатый скот эти люди обозначали словом «говядо». Отсюда наше «говядина» (т.е. мясо крупного рогатого скота).

Язык даёт нам возможность не только узнать исторические события, но и позволяет дать характеристику исторического бытия того или иного народа в определённую эпоху. Практически во всех мировых религиях письменность дана человеку свыше. В исламской доктрине сам Аллах является создателем письменности, то же самое наблюдается и в Иудаизме и Христианстве Моисей получил скрижали, на которых перстом 
божьим начертаны заповеди. Кстати старославянское обращение: «Гой-еси» уходит корнями в древнееврейский язык. «Гой» значит свой человек, член общины, рода, племени. Изгой - чужой (из чужих), не наш, изгнанник. И обращение: «Ой ты Гой-еси, царь Иван Васильевич!» означает признание данного царя своим (нашим). В раннем христианстве на Руси весьма широк, было распространено почитание такого понятия как «Овен». Таинственный и неординарный «свет» отождествлялся с образом Бога. Белый свет - мир, созданный Творцом, осветившим его. Свет и свят - слова однокоренные. Об этом упоминает Ф. Ирзабеков, говоря: «Кто светел, тот и свят». О его книге «Бытие русского слова» будет сказано в дальнейшем.

Глагол div - светить, лучиться, блестеть уходит корнями в санскрит. Этот глагол является родоначальником имени Зевса и славянских оборотов «диво - дивное», диковинное. Славяне считали себя внуками Солнца (Даждьбога). Эпитеты «солнышко ясное», «солнышко красное», происходят именно отсюда. «Красный» значит «огненный», «яркий», «светлый»- эти признаки у древних 
славян характеризовали Солнце. Таким образом, понятие «свет» постепенно интерпретируется в понятие цвет, и именно красный.

Понимание языка представляет собой осознанное действие, заключающееся в повторении логико-смысловых операций носителя языка. Причём действует он (носитель языка) в рамках языковых правил. Такая масть чётко прослеживается у А. А. Багаутдинова. По его мнению, понимание должно носить деятельный, активный характер. Можно сказать, что в философском аспекте «языковая игра (правила)» призвана охватить поведение человека в комплексе, как предпосылки всякого следующего опыта.

Таким образом, задача философии в осмыслении языка, как такового, в данном случае русского, заключается в описании языкового поведения, выраженного в единице как языкового, так и неязыкового бытия людей. «Язык впервые мостит пути и подступы для всякой воли к размышлению». Без слова любому свойству не хватит того измерения, в котором оно могло бы обрести себя и оказать воздействие. Причём язык никогда не есть 
просто выражение мысли, чувства или желания. Язык - то изначальное измерение, внутри которого человеческое существо впервые оказывается в состоянии отозваться на бытие и его зов, и благодаря этой отзывчивости принадлежать бытию [23.87]. Проблема языка имеет весьма глубокую историю. Однако особенно остро она проявляется на рубеже XXXXI веков. Чем это вызвано? Сближение общенаучного знания с социогуманитарным и культурой отражает общую тенденцию развития современного познания [17.14] и вырабатывает

вектор лингвистикопознавательного характера, связывающий язык с явлениями коммуникаций. Данные процессы обусловлены интенсификацией социальной жизни и глобализацией ментальных, мировоззренческих, общественных процессов.

\section{ГЛАВА Ш. РУССКИЙ ЯЗЫК КАК НОСИТЕЛЬ БОЖЕСТВЕННОГО ОТКРОВЕНИЯ.}

Как уже отмечалось ранее, язык есть Божественное откровение, данное людям. 
Сакральный характер языка подтверждается текстами священного писания. Апостол Иаков говорит: «кто не согрешает в слове, тот человек совершенный, могущий обуздать и всё тело». Причём владение языком предполагает ответственность его носителя перед создателем и перед людьми. В Евангелии от Матфея говорится: «За каждое праздное слово, какое скажут люди, дадут они ответ в день суда». В разговорной речи, пословицах и поговорках также указывается на ответственность за употребляемые слова: «Слово - не воробей, вылетит - не поймаешь», уголовный жаргон (язык арго): «Фильтруй базар» (следи за разговором, контролируй его, поскольку придётся «за базар (за слова) ответить», иными словами, наступит ответственность за сказанное. Автор не зря упомянул криминальный сленг, поскольку его щупальца уже проникают в речь русскую и у академика, и у бродяги. Факт этот вызывает тревогу у многих специалистов. По выражению В. К. Кюхельбекера: «Народ - это существо в принципе духовное, а язык, на котором он изъясняется, может быть рассмотрен, как народная душа». И, надо сказать, состояние 
этой души сегодня весьма болезненно. Развитие языка - вполне естественный процесс, и его изменения обусловлены соответствующей эпохой, но изменение изменению рознь. И сегодня наше морально-нравственное состояние как нигде более отражается в конструкциях языка. Существует толковый словарь, в котором зафиксированы изменения русского языка, произошедшие во второй половине двадцатого века. Что же мы там найдём? Действительно, новых слов и выражений там весьма много. Но что это за слова? «Деньги» теперь стали именоваться «бабками», вместо долларов «баксы», вместо любимый - «бой-френд», одежда - «прикид», подросток - «тинэйджер». Бред какой-то. Почему вместо «многообразия» мы должны употреблять чужой «плюрализм». А такие слова как «ништяк», «мочить», «стрелка», «разборка» проникли в наш лексикон из тюремного обихода. Если уж глава государства призывает «мочить в сортире», то дальше идти уже некуда. Конечно, ничего, кроме смеха, не вызовет эта фраза - «порешить в нужнике», но есть всё же литературные нормы. Так что если уж касаться участи террористов, то есть предложение «ликвидировать их в любом 
месте, в том числе и отхожем». Также, с позволения сказать, «англоязычные словечки» как «дампинг», «имиджмейкер», «лейбл», «рэпер», «шопинг», «секьюрити» засоряют наш язык как криминальный сленг. Недавно автору пришлось вступить в спор с одной из коллег по поводу слова «саммит». По её мнению, а она преподаёт экономику, никаких аналогов этому слову в русском языке нет, поскольку его смысловое значение гораздо богаче, чем «собрание». Пришлось ей возразить, что вполне уместным аналогом могут служить «деловое общение», «деловая встреча», «совещание». А на контраргумент коллеги, что сегодня мы не можем избежать американизмов и англицизмов, так как вся экономика содержит огромное количество англоязычных терминов, все-таки говорю: «Да, только понятие экономика нам чуждое». О чём писали нам ещё Д. И. Менделеев и князь С. Н. Трубецкой. Потому и не приживается она у нас. Горе - экономисты превратили Великую державу в страну мелких и средних лавочников. И все эти «инвестиции», «фьюгеры», «ваучеры», «прайс-листы» - пустой звук для русского сердца. В России всегда вели хозяйство и занимались хозяйствованием, а не 
экономикой. Экономика предполагает извлечение сверхприбылей за сравнительно короткий срок, независимо от последствий, иными словами, любой ценой. Хозяйствование есть разумное использование имеющихся ресурсов. Получение прибыли в разумных пределах. И, самое главное, ликвидация негативных последствий от вмешательства человека в естественные процессы. В отличие от экономики, принцип которой - «после нас хоть потоп», хозяйствование учитывает интересы грядущих поколений. Ну, а насчёт терминологии смею Вас уверить, что А. Никитин в Индии побывал, когда ещё ни США, ни Риккардо, ни А. Смита не было, и о менеджерах никто ещё и слыхом не слыхивал. Так что вполне можно успешно хозяйствовать без инвестиций, но с вкладами и поступлениями, без «шопов», но с магазинами, без маркетинга, но с рынком и базаром. И англо-американские сорняки нам не нужны. Такая вот вип-тусовка. По сути своей этот «новояз», либо иноязычные слова, отражают традиции и реалии, не свойственные как русской нравственности, так и русской традиции, а зачастую характеризуют и вовсе 
отвратительные явления. Обидно то, что сегодня даже некоторые литераторы и руководители всех рангов используют эти варварские обороты. А главное ведь гордятся этим, считая такую речь современной, адекватной, характерной для «крутых» парней. Хотя и представительницы прекрасного пола здесь, увы, ни в чём не уступают. В самом деле, эти варварские обороты породили термин, уже ставший официальным: «варваризация языка». Специалисты B cфepe языкознания характеризуют нынешнюю трансформацию языка «третьей варваризацией». Первая такая волна пришлась на эпоху правления Петра I, вторая на послереволюционный период. Если смотреть правде в глаза, то можно заменить мягкозвучащий модный термин «сленг» на жёсткопроизносимый «жаргон», и мы увидим происходящую жаргонизацию русского языка. Разговорная и литературная речь всё более жаргонизируется. Лингвисты выявили, что в период 1960-1980 годов молодёжный жаргон в большинстве случаев основывался на иноязычных заимствованиях. Это можно было объяснить романтизацией европейского образа жизни. В наше время преобладает тюремная 
романтика и, соответственно, тюремный жаргон. Бизнесмены, политики, артисты, писатели - все стремятся «ботать на фене» (то есть изъясняться на воровском жаргоне). Сегодняшний студент, к большому сожалению, прежде чем дать определение по необходимому вопросу, зачастую произносит примерно следующую тираду: «короче», «в натуре», «как бы», «ваще», «это самое», «значит», «блин». «Ну, вроде, как бы, пространство, поделенное на время, блин». И это, увы, не гипербола. Вот уже поистине «в натуре, надо репу чесать». А по-русски сказать - надо думать. И, выражаясь словами замечательного литературного героя Сани Григорьева из книги В. Каренина «Два капитана», тут «Есть над чем подумать».

Русский язык испытывает сильнейшее влияние, давление со стороны криминального жаргона (воровского арго), который несёт идеологию индивидуализма, потребительства и бездуховности. Более того, нынешний жаргон способствует разобщению людей. Так, например, выражения «отвали», «отвянь» содержат безразличие или даже неприязнь к другому человеку. Равнодушие и безразличие, холодный эгоизм несут в себе слова и 
выражения «параллельно», «сугубо фиолетово» и «по барабану». Весьма интересны данные статистики. Так, сегодня около $60 \%$ жаргонизмов можно определить в групповую тематику «секс», а свыше $30 \%$ тем или иным образом связаны с распространением, хранением и способом употребления наркотиков. Вот итог западного образца жизни, таковы сегодня ценностные ориентиры, навязываемые Западом нашему обществу, такова сущность рвущихся к власти чиновников и политиков, имеющих зачастую криминальное прошлое и диктующих обществу свои законы. Носителей русского языка можно условно разделить на две группы. Первые - это те, для которых литературный язык является лишь средством самовыражения и общения на уровне общества, болтовни и глумления над кем-либо, эти люди издеваются над сакральной сущностью языка, стараются подменить его смесью из жаргонизмов и «непереваренных» иноязычных слов и нецензурной брани. Подобного рода носители языка желают, в конечном итоге, уничтожить русскую культуру, русскую духовность и самобытность русской истории. Они стараются сделать Россию 
униженной частицей пресловутого глобального мира, отводя ей место на задворках истории. И вторая группа - это те, для кого русский язык поистине свят. Именно эта группа с Божьей помощью противостоит агрессии первой группы. В настоящее время идёт самая настоящая битва на языковом поле, она носит характер брани духовной между жаргонизированным «новоязом» и литературным языком. Можно с уверенностью утверждать, что ареной за идеологическое будущее России является русский язык. Мы должны в меру своих сил изыскивать возможности служения отечеству и его святыням, одной из которых является русский язык. Особенно хочется остановиться на таком сокровище национальной культуры, как церковнославянский язык. И если мы хотим сохранить национальную ментальность, свою самобытность, нам необходимо вернуться к изучению этого языка в школах, хотя бы, для начала, в кружках и факультативах в рамках школьного компонента. И необходимо, жизненно важно, увеличить часы русской словесности. Иначе вымрем духовно. Можно прожить без молекулярной физики или 
квантовой механики, но без языка, словесности, языковой культуры человек станет чем - то вроде робота из фантастических произведений Айзека Азимова. Отсутствие языковой культуры приведёт не только к деградации личности, но и духовному обнищанию всего народа. В этой связи хочется ещё раз подчеркнуть, что нельзя, недопустимо губить отечественное образование так называемыми реформами. У нас сложилась замечательная система образования ещё в дореволюционной России, а затем и в СССР. Нам незачем копировать западную модель образования. Пора уже чиновникам от образования понять и осознать, что деятельность их пагубна. Учёные и педагоги это понимают. Нам не нужны бакалавры - недоучки. Надо вернуть классическое русское образование. Бессмысленно требовать от образования рентабельности. Образование есть передача образа и стяжания духа. И материальные оценки (финансовые), а также пресловутые образовательные стандарты здесь недопустимы. Образование как процесс есть передача образа, духовная деятельность. Загнать это в рамки стандарта - значит погубить духовную 
сущность образования. А уж понятие «образовательные услуги» и вовсе нонсенс. Услуги можно оказать в парикмахерской, но никак не в учебном заведении. Учебное заведение не зря называют храмом науки. А храм - место святое. Эдак мы с вами дойдём до того, что будем церковную службу называть сакральными услугами. Не дай Бог дожить до таких дней. Опомнитесь, господа чиновники!

Но вернёмся к церковно-славянскому языку. Ведь это, по большему счёту, наш родной язык. От него идут истоки современного русского языка. Слушая текст на церковнославянском, ощущаешь красоту, совершенство, богатство лексики, строя и лада церковнославянского языка и строгую красоту изображения букв в кириллице. Не зря, видимо, говаривал М.В. Ломоносов: «русский язык не будет подвержен упадку, коль долго Церковь Российская славословием Божьим на славянском языке украшаться будет». Ученики словенские Кирилл и Мефодий святые и равноапостольные создали азбуку именно для богослужения. Это общий для всех славян язык общения с Богом. Пожалуй, никакой другой язык не является в этом смысле освящённым 
благодатью Божьей. Коль скоро язык этот предназначен для общения с Богом, он свят, сакрален, могуч и велик. Как справедливо указывает академик В.В. Виноградов, церковнославянский язык «национализирован русской культурой и, будучи священным языком, постоянно обогащает и развивает народную речь». Через церковнославянский язык наш литературный язык сопричастен к греческой, и византийской, и античной языковой традиции. Вот простой пример. Читая русские былины, часто встречаешь слово «исполнять». Например: «...исполнить тебе, добрый молодец», «исполнять тебе, княже Владимире - ясно солнышко». А на литургии Василия Великого (или на архиерейской литургии) в конце церковной службы хор поёт: «Исполаэти, деспота». Улавливаете созвучие? Да, верно, общий корень здесь «исполать» вечная (добрая) слава тебе, добрый молодец. А слово «деспот» - это господин (опять же Господь). Таким образом, возникли смысловые конструкции: «вечная слава тебе, добрый молодец» и «вечная слава тебе, господин». Так, из древнегреческого эти слова вошли в церковнославянский, а затем в современный 
русский язык. Об этом автор уже упоминал. Русский язык и до наших дней сохранил сущность свою языка-моста, сакрального, удерживающего начала и связи богоизбранного народа с Творцом всего сущего.

Россия сегодня находится на ответвлённом участке своего исторического пути. Необходимо преодолеть множество кризисных моментов современного российского общества. Это невозможно осуществить без духовно-нравственного очищения, «подъёма общества, без опоры на классическую и народную, выдержавшую испытание временем, русскую культуру народов России» [18]. Упрямая старуха статистика свидетельствует о том, что язык каждого народа, большого или малого, содержит в своей конструкции сведения о Боге и вере, своеобразное представление о создателе, которое прочно вошло в жизнь того или иного народа. Причём независимо от того, какую религию этот народ исповедует, единобожие или многобожие. Вспомним Н.В. Гоголя. В его произведении «Выбранные места из переписки с друзьями» читаем: «Нужно вспомнить человеку, что он вовсе не материальная скотина, но высокий гражданин 
высокого небесного гражданства. Покуда он хоть сколько-нибудь не будет жить жизнью небесного гражданства, до тех пор не придёт в порядок и его земное гражданство». Град Небесный и житель града сего как раз и именуется гражданином. У нас же с понятием гражданин волей или неволей ассоциируется словосочетание «гражданин начальник». Опять тюремная какая-то лексика. Что в данном случае обусловлено историей нашей многострадальной страны. Уродливое искажение языка началось сразу же после революции 1917 года. Люди отвернулись от Бога и сконструировали свой кощунственный язык, советский новояз. И появились у нас «нарком прос», «комбед», «бомж», «зек», а вместо сестры милосердия - «медсестра». Сравните, как серо они звучат, как безличны эти новые словечки. Сестра милосердия - здесь и сострадание, и сопричастность, и забота, и стремление облегчить боль. В этом слове чувствуется христианская поэтика, романтика, если хотите. Или, например, «босяк», «бродяга», «бездомный» - сколько в этих словах горести, жалости, образности. И холодное безжизненное «бомж». Или ещё «узник», 
«каторжник», «арестант» - очень чётко и образно определён статус человека, преступившего закон. Эти слова несут большую смысловую и морально-нравственную нагрузку. И ничего нам не говорит холодное, резкое, как звук пилы, «зек». И всё это произошло отнюдь не само собой. Человек перестал рассматриваться властными структурами как прообраз создателя, как его творение. Человек стал рассматриваться как среднестатистическая единица населения, безличный элемент системы. Таким вот образом мы дошли до того, что вместо человека, вместо его лица, стали употреблять «рыло». В обиход прочно вошло выражение «один килограмм (пара, штука, бутылка, и т.д.) на рыло». Так и хочется воскликнуть: «Прости их, Господи, ибо не ведают, что творят». В те далёкие времена появились в нашей стране ужасные имена: «Марлен» - Маркс и Ленин, «Даздраперма» - да здравствует первое мая, и т.п. А ведь нам с детских лет известно из замечательной книги A.Н. Некрасова «Приключения капитана Врунгеля» - «как вы судно назовёте, так оно и поплывет». Тут уж, как говорится, приплыли. А ведь можно и должно вести речь о философии 
имени. Имя - это богатейший кладезь, важная составляющая личности. Ведь и Бог личностен. И никуда от этого не уйти. Можно даже определить имя как мистический образ личности. Фамилия человека связывает его с целой группой людей - родом, причём как со стороны отца, так и матери. А отчество связывает человека непосредственно с отцом. И знание своей родословной, уважительное отношение к отцу и матери даёт характеристику человеку, помогает нам дать его личностную оценку. Ведь обязанность уважать (чтить) отца и мать - одна из важнейших заповедей, изложенных Христом в Нагорной проповеди. И родословная Христа изложена весьма подробно, чтобы мы могли понять важность этого элемента нашей жизни. В ужас приходишь от попыток западного общества заменить святые в общем-то слова «мать» и «отец» на «первый родитель» и «второй родитель». Поистине чтото бесовское в этом проглядывает. Это характеризует западное общество, как деградирующее [9. 156]. Вспоминая об имени, его значении, хочется сослаться на замечательного учёного отца П. Флоренского. Он подчёркивал, что тема личности «даётся 
именем, и всё остальное - лишь простая разработка этой темы по правилам контрапункта и гармонии... Имена - такие произведения из произведений культуры, высочайшей цельности, и потому высочайшей ценности, добытые человечеством» [22. 237]. Знаменитый русский философ А.Ф. Лосев так говорил об именах: «...имя есть жизнь, только в слове мы общаемся с людьми, с природой, только в имени обоснована вся глубочайшая природа социальности во всех бесконечных формах её проявления; это всё отвергать значит впадать не только в антисоциальное, но и вообще в античеловеческое, в антиразумное одиночество, в сумасшествие». Человек, для которого нет имени, для которого имя только пустой звук, а не сами предметы в их смысловой явленности, этот человек глух и нем, и живет он в глухонемой действительности. Если слово не действительно, и имя не реально, не есть фактор самой действительности, наконец, не есть сама социальная (в широчайшем смысле этого понятия) действительность, тогда существует только тьма и безумие, и копошатся в этой тьме только такие же безумные и глухонемые чудовища. 
Однако мир не таков [23. 127]. Обращение к человеку по фамилии, а ещё хуже по прозвищу, как принято, например, в подростковой среде, или по кличке, что характерно для криминальной среды, не только унижает человека, но и, по сути своей, есть дурной тон. Самое уважительное отношение мы выказываем, когда обращаемся к человеку по имени и отчеству. Необходимо отметить, что эта пагубная тенденция коснулась не только имён собственных, но и имён нарицательных. Многие слова мы превратили в аббревиатуры. Аббревиатура не вызывает духовных ассоциаций и не может пробуждать чувства именно благодаря своей генетической бесчувственности. Лишённое корней русского языка слово, зачастую, лишается смысла. Скажем, слово «душегуб» или «убийца» моментально вызывают отвращение, страх, неприязнь. И англоязычное «киллер» холодное и бесчувственное. Поэтому и к жизни, и к личности мы стали относиться холодно и равнодушно. Недаром выражение «вырвать с корнем» означает уничтожить. Вырывая русские корни, мы уничтожаем русский язык. Безкорневой язык свидетельствует об 
отсутствии связей не только с предками, но и с Богом. Ведь русский язык тем и могуч, что не просто лингвистическая система, но живое слово, целая жизнь, одарённая Божественным словом.

Обратите внимание на два слова: «свят» и «святой». Связь улавливается сразу. И здесь не только звуковое, если хотите, поэтическое свойство - это истина, выраженная и закреплённая в слове. Бог - свят. Как сказано в священном тексте «... и не было в нём ни капли тьмы». Неспроста обиталища многих святых находили по дивному свету, струящемуся из их келий. Обращаясь к Богу на утренней молитве, мы провозглашаем: «Ты то еси истинный свет, просвещай и освещай всяческая...». Итак, свет, освещение, просвещение и святость - звенья одной цепи, если можно так выразиться. Причем можно провести параллель с другими языками. Язык любого народа, независимо от его конфессиональной принадлежности, свидетельствует о том, что его носители призваны к жизни Богом (Христом). В нагорной проповеди Христос, обращаясь к своим ученикам, говорит: «Вы свет мира». А в некоторых тюркских языках, в частности, в 
азербайджанском, грамотный, воспитанный, образованный человек (интеллигент) звучит как «зияллы». От тюркского «Зия» - свет, луг. Действительно мудро народное сознание, определяющее, что поистине интеллигенция, элита нации, должна светить людям. На Востоке усопшему желают, чтобы могила его наполнилась светом. Западное определение слова интеллигент очень узкое, в нём заключена лишь профессиональная особенность работник умственного труда. В русском же понимании слово «интеллигент» - это состояние души. Можно окончить два или три ВУЗа и не быть интеллигентом в полном смысле этого слова.

Опасность, и притом не малая, заключается в том, что мы, не задумываясь, употребляем иностранные слова и постепенно забываем свой родной язык. Телевидение, интернет, реклама навязывают нам иностранное слово там, где они совершенно не нужны. Где бы мы с Вами не оказались - в Петербурге, Перми или во Владивостоке - везде мы видим рекламные щиты или, как их сейчас называют, «баннеры» (то ещё словечко). Так вот хотелось бы остановиться на их 
содержании. С точки зрения лингвистики, они, зачастую, ни к какому языку не относятся, хотя в большинстве случаев пишутся на латинице. Например, такое словосочетание: «Банк Vostok». Вот уж поистине смесь «французского c нижегородским». Напишите «Банк Восток» или уж «Bank the ost», а то «ни то - ни сё», как говорится. Я прекрасно понимаю, что проще сказать «карбюратор», чем устройство для фильтрации топлива (бензина) и его последующего впрыскивания в рабочий цилиндр. То же можно сказать и об инжекторном двигателе. Но есть русский аналог или давно обрусевшие иноязычные слова, понятные всем. Такие иноязычные слова обогащают язык, поскольку их, бывает, просто никак не заменишь, например, картошка произошла от немецкого «картухель». А вот сапожное ателье «Skorohod», согласитесь, звучит и смотрится диковато. Или написанные кириллицей англоязычные конструкции, их и словами-то не назовёшь, допустим, предложение: приобрести в собственность «экофлет». Это сразу и не разберёшь, что за диво такое. Может и есть резон купить. Или купить таун-хаус. Простите, но почему-то в 
памяти сразу всплывает болезнь Дауна и Хаос. То есть сумасшествие и беспорядок. Оказывается «экофлет» с английского flat квартира, а есо - от экологии. Получается квартира с чистой экологией. Ну, а таун-хаус опять же от английских слов town - город, house - дом. Просто городской дом. Но жить в городском доме - банально, а в таун-хаусе - это круто! А набившие оскомину хот-доги переводятся как «горячие собаки». Ну, разве не бред? Или, например, «Стардогс» - звёздные собаки, «Вэй - парк» - парк дорога (аллея). Ну, скажи сквер. Ан нет - не круто. Или вот модное нынче словечко «менеджер». Согласен, звучит красиво. Даже специальность такая появилась в институтах. Вот парадокс - в дословном переводе это «управляющий» («управленец» в просторечии), что соответствует старому слову «приказчик». Ну, что-то вроде старшего продавца. Зачем же, господа, огород городить?

Получил выпускник диплом с квалификацией: «Бакалавр менеджмента». И куда его, что с ним делать? Честное слово, я бы это диво дивное на работу к себе не взял. Мы не только язык, мы всю систему образования изуродовали. И, как ни печально, это 
целенаправленный процесс, идущий из верхних эшелонов власти или при их прямом попустительстве. Волей - неволей вспомнишь бессмертного А. С. Пушкина: «чем непонятней, тем учёней». Или старую добрую репризу А. Райкина: «Я выражаюсь по-научному - меня мало кто понимает». Но смех - смехом, а тенденция весьма тревожная. Сегодня всем тем, кто каким-то образом связан с формированием современного русского языка, кто радеет о его сбережении, приумножении - политическим деятелям, литераторам, журналистам, учёным, учителям необходимо осознать значение языка в жизни нации и взять на себя ответственность за его будущее, от этого зависит судьба страны. Мы должны сохранить язык русский как цементирующую основу государственности. Об этом говорит и академик Олег Трубачёв. Нам, огрубевшим от нашей материальнонеблагополучной жизни, всегда следует помнить, что распад СССР, как материальной конструкции, отнюдь не означает полного и бесповоротного его крушения, ибо последнее, смею надеяться, не затронуло лучшую, в полном смысле этого слова, нетленную часть нашего союза - языковой союз, русский 
языковый союз. Исчезают с нашей земли пельменные, блинные, шашлычные. Всюду уродцы: бизнес-ланч, кебаб-хаус, кафе-хаус, блин-хаус. вместо меценатов, пожертвователей И

благоустроителей расползлись по нашей многострадальной земле спонсоры и инвесторы. Когда же, когда же кончится этот кошмар и издевательство не только над языком, но и над самой ментальностью русской. Прав был А.С. Шишков, тысячу раз прав: «Полезно ли славянский превращать в греко-татаро-латинофранцузско-немецкий язык. А без чистоты и разума языка может ли процветать словесность?» [24. 321].

Не меньшую опасность таит в себе компьютерный сленг. Как вам нравится необходимость апгрейдить машину, дачу, квартиру? Какие-то не совсем адекватные ассоциации возникают. Ну, почему не сказать куда более удобопроизносимое «усовершенствовать» (улучшить от английского «upgrade» - усовершенствовать. Мы уже перестали общаться - мы «чатимся». Характеризуя неадекватную личность, мы не употребляем даже своих родных сленговых 
конструкций типа «чокнутый», «повёрнутый», «стуканутый» и т.п. Теперь в ходу модное и крутое «крезанутый», от английского «crazy»безумие. Абсолютно чуждый русскому уху сленг, в котором не просматриваются русские корни, прочно вошёл в наш лексикон. Что печально - не только молодёжь, но и солидные люди, занимающие значительные должности, грешат подобного рода слабиной. Англоязычный сленг беззастенчиво вытесняет наши родные, исконно русские слова. По сути своей происходит деградация языковой культуры. Вопросы соотношения образования и культуры, их взаимозависимости сегодня так же важны, как и во времена адмирала А.C. Шишкова, они не теряют своей актуальности и практической значимости.

Понятие культуры, в логическом аспекте, является более широким, а образование в данном случае выступает как элемент культуры. Русская культура - это более чем тысячелетний пласт истории. Это, прежде всего, православная культура, языковая культура. Естественно, что русская культура и русский язык испытывают на себе влияние культур и языков других народов, как населяющих Россию, так и 
живущих за её пределами. И в свою очередь они оказывают своё влияние на них. Таким образом, происходит взаимопроникновение и взаимодействие культур. Причём русская культура во многих странах выступает в качестве определяющей доминанты. Язык неотъемлемый элемент культуры. А вот языковая культура сегодня стремительно снижается. Речь старшеклассника и студента, да и не только, пестрит всевозможными смайликами, аськами, гайами и прочими словечками - уродцами. Слишком много словпаразитов. Зачастую студент не может логически обоснованно сконструировать фразу, выразить свою мысль, не используя сленговых выражений. А такие слова, как: «значит», «ну», «короче», «типа» стали атрибутами современной речи. Что же происходит? Почему же литературный русский язык претерпевает такие негативные изменения? С одной стороны, насильственное навязывание иноязычных слов средствами массовой информации, рекламой, с другой, сама система современного образования. Именно поэтому молодёжь старшеклассники и студенты не могут правильно изъясняться. 
Количество часов по русской литературе в старших классах просто мизерно. Да и изучать А.И.Солженицына вместо, скажем, Шолохова весьма нецелесообразно. Вузовские курсы «Этики делового общения» и «Русский язык и культура речи» очень кратки и зачастую носят характер элективных курсов. Снизилась культура речи и самих педагогов. Невольно стал свидетелем разговора двух подростков, которые готовили в качестве домашнего задания по литературе поэму А.С.Пушкина «Евгений Онегин». Они характеризуют текст поэмы, и один другого спрашивает: «Что-то я не врубаюсь. У Онегина чё, две «тёлки» было?» Представляете вопросик - каково? Слышал бы подобное А.С.Пушкин, он бы до дуэли не дожил. Резко снизился уровень речевой культуры в средствах массовой информации. Если в 60-70-х годах прошлого столетия речь дикторов радио и телевидения могла служить эталоном грамотности, то сегодня, увы, многие из них не владеют ни стилистикой, ни грамматикой. Поэтому сплошь и рядом на страницах периодической печати возникают и звучат на радио и телевидении различного рода «договора», «квартал», «средства», 
«бухгалтера» и т.п. Где же корректоры? А порой yст

высокопоставленного государственного мужа

слышишь такой деепричастный оборот, что невольно вспоминаешь Чеховскую «Жалобную книгу». Помните? «Подъезжая к городу, у меня слетела шляпа». Вот и выходит: «Хоть ты и Ивановседьмой, а дурак». Автор полагает, что следует внести соответствующую корректировку в школьную программу, увеличить количество часов русского языка, вернуться к изучению классической русской литературы.

А в ВУЗах, независимо от профиля, увеличить количество часов по таким дисциплинам как «Русский язык и культура речи», «Этика делового общения», «Культура делового человека». В периодических изданиях создать более строгую корректорскую службу, предусмотренную так же на радио и телевидении, желательно ввести цензуру. Только так мы сможем сохранить богатство, культуру и методику русского языка $[20,176]$.

Весьма анекдотичный случай приводит Ф.Ирзабеков в своей книге «Тайны русского слова», воспроизводя диалог двух старушек. Одна другую спрашивает: «Ты масло в 
магазине брала?» «Нет,- отвечает собеседница. В шопе». И им бедным невдомек, что «шоп» и магазин суть одно и то же. Только «шоп» - это английское слово, shop - как раз и значит магазин. Мы настолько покорились иноязычному сленгу, что скоро свой язык совсем забудем. И придется с русского на русский язык переводить. Парадоксальная ситуация. Теперь у нас вместо терпимости толерантность, вместо разномыслия плюрализм, вместо согласия - консенсус. Мы, русские люди, теперь не можем куражиться, потому что вместо таких чувств как задор, азарт, кураж нам предлагают испытать драйв и ловить кайф (от арабского «кейф», что значит «отдых в оазисе»). А вместо старого и доброго кино у нас теперь блокбастеры и ремейки. И музыки в них нет теперь, а есть саундтрек. Кинопроб и конкурсных отборов тоже нет, зато есть кастинг. И вся эта тарабарщина прочно обосновывается в сознании, особенно молодых людей, они уже не могут не только сочинение написать, но и простой документ составить не в состоянии. Недавно предложил одному четверокурснику написать объяснение по поводу нарушения учебной дисциплины. Так он 
не справился с этой задачей, заявил, что не умеет такие бумаги писать. Чему учат в школе? Бодибилдингу, шопингу или сайдингу? Только не полезным делам. В СССР, хорошо помню, в шестом классе учили писать доверенность, заявление, объяснение, расписку и т.п. Зачем было ломать установившуюся, зарекомендовавшую себя систему образования? Зачем нам этот хромающий на обе ноги бакалавриат? Зачем нам ничего не дающая Болонская конвенция? Хающие лебезить перед Западом. Мы носители одной из древнейших культур. Нам должны подражать, на нас оглядываться. А мы все с надеждой смотрим на бездуховно заевшуюся Европу, на это деградирующее общество, забывшее заповеди Христовы и поклоняющееся золотому кольцу.

Сегодня, оценивая власть, необходимо учитывать, какие изменения вносит она в духовную сферу, в том числе и в развитии национального языка. Духовная жизнь - вещь чрезвычайно тонкая. Она не укладывается в схемы твердолобых чиновников. Тем не менее важность и значимость духовной составляющей для нации, для страны не менее важный критерий, чем выплавка стали, добыча нефти и 
производство электроэнергии. О власти можно судить по тому, что она сделала для сбережения и приумножения русского языка. К сожалению, следует констатировать, что стилистика речи руководителей, вплоть до самого высшего уровня, страдает теми же неудачами, что и речь среднестатистического россиянина. Достаточно вспомнить фразу, прозвучавшую из уст главы администрации Президента Б.Н. Ельцина «Пипл все схватывает», ставшей притчей во языцех. Так что для некоторых чиновников мы не нация, а просто безликие «пиплы», бросающиеся на подачки. К слову сказать, в России с давних пор в ходу преклонение перед иностранщиной. Достаточно вспомнить повальное увлечение российского бомонда французским языком. Даже А.С.Пушкин в юном возрасте куда более свободно изъяснялся на французском, нежели на родном языке. Слава Богу - няня его, Арина Родионовна, привила ему любовь к языку русскому и к России вообще. Кто знает, как бы развивался наш литературный язык, если бы не старания этой простой русской женщины. В то же время хочется показать, как народная смекалка, остроумие, язык народный метко и 
хлестко обозначали статус французов захватчиков, пришедших в Россию в составе армии Наполеона.

Отступавшие голодные и промерзшие французы часто попрошайничали у ограбленного ими же населения. Прося кусок хлеба, они обращались к людям со словами «шар ами». Так появилось наше, уже русское слово «шаромыга». А обращение « шевалье» интерпретировалось, и не безосновательно, в «шваль».

Издавна политики и военачальники были убеждены в одной истине. Если военный поход требует огромных экономических затрат, напряжения духовных и физических сил, связан с угрозой жизни его участников, то второй способ покорения противника гораздо экономичнее и безопаснее, а эффект тот же, если не больший. $\mathrm{O}$ чем идет речь? О вытеснении родного языка из речевого оборота противника. Победив язык, можно говорить о победе над врагом. Об этом свидетельствует интересная книга « Тайная история нового французского двора». Есть там такой эпизод, повествующий о встрече министров Франции за обедом у принца Людвига. Вот какую мысль на 
этом обеде высказал министр Порталис: «всеобщее употребление французского языка служит первым основанием всех связей, которые Франция имеет в Европе. Сделайте, чтобы в Англии также говорили по-французски, как в других краях. Старайтесь истребить в государстве язык народный, а потом уже и сам народ. Пусть молодые англичане тот час посланы будут во Францию и обучены одному французскому языку; чтобы они не говорили иначе как по-французски дома и в обществе, в семействе и в гостях; чтобы все указы, донесения, решения и договоры писаны были на французском языке - и тогда Англия будет нашей рабою». Это пожелание сегодня весьма актуально, поскольку в плане А.Даллеса говорится об изъятии русского языка из обихода русского народа. Это приведет к вырождению

нации.[11,www.zapret117.narod.ru] Вот и получается, что все в этом мире взаимосвязано. И засилье иноязычных сленговых конструкций - явление хорошо продуманное и спланированное. 
ГЛАВА IV. СВЯТОСТЬ ЯЗЫКА И СВЯТОСТЬ НАРОДА.

Кто светел, тот и свят. О том, что святость и свет - слова близкие по значению мы уже говорили. Теперь настало время поговорить о святости языка и его носителя. В просторечии часто понятие «святой»- не тот, кто находит в себе силы осознать, осмыслить свой грех, искренне покаяться и вновь к этому греху не возвращаться. Споткнулся - вставай, отряхнись от грязи и иди дальше. Можно ли говорить о богоизбранности народа и языка? Вполне. Ведь тот факт, что кириллица и церковно-славянский язык создавались как раз для Богослужения и чтения священных текстов, говорит о многом. А коль скоро язык богоизбранный, то и народ его носитель под особым покровительством Божьим пребывает. Никакой другой из известных языков не создавался специально для Богослужения. А почему вдруг Москва - третий Рим? Никак не могут понять молодые. Да не вдруг, друзья мои, а по предначертанию Божию. Христианство зародилось и развилось на территории Древнего Рима. Вот Вам первый Рим. Затем Византия стала оплотом христианства, в частности, Православия. Вот 
Вам второй Рим. После падения Константинополя центром Православия стала Москва-третий Рим. Прав был старец Филофей, писавший, что Москва - третий Рим. Два пали, а четвертому не бывать. То есть Москва остается центром Православия до скончания века сего. Ведь именно в Москве на кремлевском холме нетленно покоятся святые мощи митрополитов, патриархов, насельников Града Небесного. Святость в звоне колоколов, в прихожанах, спешащих на литургию или терпеливо дожидающихся исповеди, подходящих ко причастию. Смиренно стоит народ перед образами Пречистой и Спаса нашего при свечах во вновь обретенных храмах. И коль сподобит Господь, останется первопрестольная святым градом до скончания времён.

Перенес Петр I столицу в новый город Петербург. За триста лет своего существования довелось ему побывать и Петроградом, и Ленинградом, теперь снова он СанктПетербург. Какое-то неустройство чувствуется в этой частой смене имен. А Москва-матушка, она как была, так и есть Москва Первопрестольная, Златоглавая, Москва 
русская. Да, сегодня, к сожалению, оскудела Москва наша. Обезобразили её нелепые скульптуры, реклама и прочая безвкусица. Нелегальные мигранты, криминальные группировки - все это не красит нашу столицу. Настанет время - сбросит она, как Василиса Прекрасная, лягушачью шкуру рекламы, пакостных картинок и архитектурноскульптурной безвкусицы и обратится в красавицу Пригожую, каких свет не видывал. Да и Родина наша Россия, Русь-матушка, Русь святая очнется от сна. Она ведь не московской окружной дорогой ограничена. Раскинулась она от берегов Тихого океана до Балтийского моря - вот сакральные рубежи Третьего Рима. Святая Москва и Святая Русь, включающая в себя Белую и малую Русь (Малороссию). Не было сроду такого названия, как Украина. Была Малороссия как часть Российской империи. А то, что сегодня называют Западной Украиной, было территорией Австро-Венгерской Империи. Так было. И хочется надеяться, что Малороссия и Белоруссия вернуться под отеческий кров государства Российского. Российская государственность, русский язык это не просто красивые слова, - это поистине 
сокровище, причем не только русского народа, это сильнейший пласт мировой культуры. Этот язык дан народу для общения с Горним миром. И душа замирает от обиды и боли, когда слышать приходится, как некоторые небрежно относятся к языку. Коверкаем, искажаем его, а порой и оскверняем, используя нецензурные выражения. Недаром говорил апостол Павел, язык - такой орган, что может много бед наделать. Как от маленькой искры может разгореться большой пожар, так и от небольшого по размеру языка может возникнуть большое зло. Как образно и точно сказано в одном из псалмов царя Давида: « Положи, Господи, хранение устам моим». Все эти: «короче», «ваще», «в натуре», «значит», «конкретно» - как мусор налипли на язык и засоряют речь. К сожалению, сплошь и рядом слышишь «договор» и множественное число «договора». Хотя со школьных лет учат: «договоры», «тракторы», «инженеры», «офицеры», «бухгалтеры» и т.д. А как искажается глагол «класть». Более $70 \%$ русскоязычного населения, не моргнув глазом, произносит: « положьте», «положь», «ложите»ужас!!! Этим грешат и специалисты высшей 
квалификации. Следует знать и помнить, что в русском языке есть глагол «класть». И производными от него будут: «положи», «положите», «клади», «кладите». А ведь спросят за каждое слово, сказанное в суде. И еще коробит слух произношение «средства», здесь ударение следует делать на первом слоге - «сре'дства». А самое страшное - это засорение речи нецензурщиной.

И молодежь, и люди средних лет, пожилые и даже женщины и дети употребляют ненормативную лексику как присказку, для связи слов. Ругань льется с экранов телевидения, ею пестрят страницы периодической печати и Интернет. Так называемые писатели, так и хочется сказать «писаки», без зазрения совести употребляют в своих произведениях выражения, именуемые матом. И более того, кичатся этим. То же самое, к сожалению, можно сказать и об артистах. Нельзя не обратить внимания читателя на тот факт, что сам по себе мат направляет против самого святого, против материнства и прежде всего против Божьей Матери. А это уже тяжкий грех. В каноне Ангелу Хранителю мы обращаемся к ней (Божьей Матери) со словами: 
«..... Христа Бога нашего Мати, яко всех творца недоуменно рождашая», это значит, что тайная сущность Богорождения остается для нашего ума недоуменной, то есть непознанной, недоступной. Именно поэтому в связи с ограниченностью нашего разума, невозможностью познать все тайны мироздания явился из уст язычников и атеистов мат, как неприятие и отвержение тайны Богорождения. Абсолютно неверным является мнение, что мат - некий атрибут «русскости», неотъемлемая составляющая русской души. Это не так. Население Руси было глубоко религиозным. Поэтому изобрести такие речевые конструкции носителям русского языка было невозможно на генетическом уровне. А сегодня даже детишки детсадовского возраста употребляют словечко «блин», что есть не что иное, как завуалированное ругательство. Сегодня мы часто употребляем иностранные слова и выражения, основанные на заимствовании из других языков. В результате получается абсурд и бессмыслица. Так, очень часто, давая характеристику человеку, произносят сексуальный, секс-символ. А теперь попробуем эту абракадабру перевести на нормальный язык. 
Сексуальный значит половой, секс - это половая жизнь. Иными словами, физиологическая функция организма. Вот и получается - «символ половой жизни», «половая бомба» и т.п. Ну, зачем, скажите, нам эти глупые американизмы? У нас есть замечательные характеристики: «желанный», «желанная», «суженый», т.е. предназначенный судьбой. И поверьте, словосочетание «секссимвол» так же глупо, как и, например, «символ пищеварения или дыхания». Не правда ли, диковато звучит? А как Вам нравятся такие обороты как: «на фига», «до фига», «по фигу»? И ведь произносят их десятки тысяч людей, не подозревая, что «фига» означает то самое место на теле, которое листком в древности покрывалось, тем самым фиговым листком. Хочется прокомментировать и часто употребляемое выражение, обозначающее интимную близость - «заниматься любовью». По сути, тоже бессмыслица. Любовь - это чувство. Чувством можно жить, можно быть обуреваемым, подавленным. А вот заниматься чувством нельзя. Давайте в таком случае заниматься злобой, ненавистью, жалостью, уважением и т.п. Налицо логическая 
бессмыслица. Если уж говорить об образном описании интимных отношений, то лучше чем в священном писании и не скажешь. Там говорится: «Познал жену». Вот так-то. Не могу не привести слова большого педагога, нашей современницы, профессора Архангельского Педагогического университета Елены Ивановны Ганимовой. Она очень емко и точно характеризует сегодняшнее состояние языка: «чем же обогатился наш язык в последние десятилетия? И обогатился ли? Бабки (в значении денег), байк (мотоцикл), баксы, грины, башлять, бодипирсинг, бой-френд, китгмен, клипмейкер, ксивник, лейба, медиаболинг, наркодоллары, ништяк, шарить, плюрализм, пофигист, прикид, рейв-тусовка, рэппер, секс-идол, секстренинг, секьюрити, татуаж, тетёха, тинейджер, транссексуал, тусоваться, хавальник, шопинг и далее в том же духе. Нетрудно заметить, что это иноязычные слова, отражающие не свойственные русской традиции и зачастую весьма отвратные реалии, или жаргонизмы, которыми сегодня считают приличным пользоваться и некоторые писатели, и политики, и ученые. Сегодня многие, не задумываясь, используют слова, которые по 
сути своей просто убийственны. Словечко достаточно модное сегодня - «козел». Ведь это не просто оскорбление, это самое настоящее проклятие. Вспомним Евангелие от Матфея. Там сказано, что отделит сын человеческий овец от козлищ. Поставит овец по правую, а козлов по левую сторону. И скажет тем (козлам), которые по левую сторону: « идите от Меня, проклятые, в огонь вечный, уготованный диаволу и ангелам его». Бросая небрежно в чейто адрес безобидное, на первый взгляд, слово, мы тем самым вершим суд, суд над другим человеком, да и над собой. Поскольку красной мыслью в Нагорной проповеди Иисуса проходит мысль: "Не судите да не судимы будете, ибо каким судом судите, таким будете судимы». Слово - очень серьезное, особо острое оружие. «Кто не согрешает в слове, тот человек совершенный, могущий обуздать и всё тело», - говорится в послании Седьмого Апостола Иакова. В подтверждение того, что на русский язык оказывается негативное давление извне, свидетельствует откровение одного из сотрудников спецслужб США, Д. Колемана, в частности, рассуждающего о том, что при помощи специально внушаемых слов можно 
осуществить управление большими группами (массами) людей. Такие слова были созданы учеными Тавистокского института человеческих отношений, входящего в состав Русского университета и Калифорнийского научно-исследовательского

Стенфордского института. Они первоначально были предназначены для американской молодежи, сознание которой планировали изменить. Сегодня США широко использует эту методику во всем мире. В том числе и при подготовке и проведении так называемых оранжевых революций.

Существует нейролингвистическое специальная программа «Изменение образа человека». Разработан так называемый разделяющий язык, вызывающий расслоение общества. Тинэйджерам и в голову не могло прийти, что все нетрадиционные ценности, к которым они стремятся, были тщательно разработаны пожилыми учеными в мозговых центрах Англии и Стэнфорда. Они были бы потрясены, обнаружив, что большая часть их «клёвых» привычек и выражений была специально создана группой пожилых 
социологов [14,177]. Внедрение в общественное сознание мысли, что молодежная культура возникает стихийно - чистая выдумка. На самом деле осознанно и целенаправленно создана низменная субкультура, направленная на планомерное изменение человека, его образа и самой сути. Весьма интересен тот факт, что ученые (в этом большая заслуга Российской Академии Наук) выяснили, что ДНК не только способны передавать информацию, но и могут воспринимать человеческую речь. Даже читаемый текст. Все это передается по электромагнитным каналам. Добрые слова, позитивно окрашенные тексты вызывают оздоровление генов. А злоба, ненависть, матерщина могут вызывать необратимые мутации. Современная наука утверждает, что всякое произнесенное слово представляет собой волновую генетическую программу, оказывающую влияние на человека и его потомков. Представьте себе, какая сформируется личность из младенца, который еще в материнской утробе слышит мат, чувствует злобу, а будущая мама к тому же еще курит и балуется пивцом? А те люди, несчастные люди, которые считают скабрезный 
язык родным, становятся псевдо - народом, поскольку изъясняются на псевдоязыке. И, пожалуй, самое страшное, что они как раз первые и поклонятся псевдоносителю. Кстати, язык ругани (мата) называется инфернальным, а по латыни inferna значит ад. А страшным (страстным) Высший суд называется потому, что судить нас будут по страстям нашим. Язык молитвы препятствует воздействию извне, что является надежной защитой OT нейролингвистического воздействия. Колокольный звон нескольких храмов, звучащий одновременно, способен изменить траекторию полета межконтинентальной ракеты. Какая же милость Божия изливается на русских людей, что им позволено обращаться к Создателю и святым Его, к Пресвятой Богородице на языке, с которым знаком с детства, который впитал и принял с молоком матери. Слова на старославянском языке звучат очень поэтично и образно, и смысл их более глубокий, чем у современных слов. И, пожалуй, главное достоинство церковно-славянского языка в том, что он совершенно не засорен сленгом. Не в состоянии бесы воздействовать на него. Слово «выну» означает «искренний», 
«открытый», «правдивый». Так и произносим: « Аз же беззаконие мое знаю, и грех мой пред Тобою есть выну». То есть с искренностью открою все мои грехи перед Богом. Южик отрога, младенец, отсюда - юность. Нудить напрягать силу. «Царствие Небесное нудится» то есть достичь его можно через напряжение сил, как духовных, так и физических. «Благословен плод чрева твоего!» - как благозвучно произносится. А на современном языке это примерно так - «хорош твой младенец». Согласитесь, что в современном переводе это выглядит намного беднее, ослабленнее. Или попробуем перевести на современный язык слова пятидесятого псалма царя Давида: «Сердце чисто сожизди во мне и дух нрав обнови во утробе моей». Будет примерно так - «сделай (создай) мне чистое сердце и состояние правдивое в моих внутренностях». Чувствуете разницу? Как музыкально звучит стих канона, читаемого при совершении Евхаристики: «Яко да Царя всех подымем ангельскими невидимо дориносима чинми». В древнем Риме существовал особый воинский ритуал. Победителя поднимали на щит на копьях со спиленными остриями. 
Поэтому, если перевести эту фразу на современный язык, получится: «Как Царя поднимем тебя на невидимых ангельских копьях без острия (дориносима). Совсем другая картина получается, и звучит неуклюже. Очень четко определял соотношение сердца и разума известнейший и по-отечески мудрый святитель Феофан Затворник. Вот что он говорил: «нынче нет удержу от совопросничества. Ум наш комар, а все пищит!». О том же свидетельствует и Библия. Мозг лишь два раза упоминается в её тексте, а сердце используется 724 раза. И надо всегда помнить, что звічеть (звечать) - значит звучать. Язык может быть интерпретирован как я зык, то есть «я» Звучащий, звучу. Об этом говорил еще адмирал Шишков. А звучать может лишь живой. Значит и язык наш живой, как живая родниковая вода. Как тут не вспомнить князя Николая Трубецкого и его замечательные слова:

«Сопряжение церковнославянской и великорусской стихии, будучи основной особенностью русского литературного языка, ставит этот язык в совершенно исключительное положение. Трудно сказать нечто подобное о каком-нибудь другом литературном языке». Хотелось бы 
отметить

Представитель любого этноса определял свою национальную принадлежность, отвечая на вопрос - «кто?» Например, француз, узбек, англичанин и т.д. А русский человек дает определение - «какой?» Исходя из сказанного, логически можно заключить, что, говоря «русский», мы ведем речь не об этнической или генетической принадлежности или не только и не столько о ней, а о нечто большем. О чем? состоянии души, о ментальности, о соборности и духовности. На первый взгляд, словосочетание «русский офицер Чохан Валиранов» звучит несколько странно. Но только на первый взгляд. Он действительно был настоящим русским офицером и служил России верой и правдой. А князья Юсуповы? Целый сонм великих людей, которых мы совершенно обоснованно называем русскими, не были ими с биологической (генетической) точки зрения. Но они были верными детьми матушки - России и русскими по духу. Это и Карамзин, и Достоевский, и Лермонтов, и Пушкин, Даль, Куприн, Гоголь, Суворов, Багратион, Барклайде-Толли, Окуджава, Левитан, Нахимов. И этот список можно еще долго продолжать. Только в 
России

сформировались

большие

этнокультурные группы, давшие России и всему человечеству много славных имен: русские немцы, русские татары, русские евреи и т.д. Аналогов нет ни в одной стране мира. Каждый из нас, независимо от национальности, возраста и вероисповедания, независимо от занимаемой должности должен приложить как можно больше усилий к изысканию способов служения России и её святыням, одной из которых, безусловно, является русский язык. Действительно, язык наш могуч, поэтичен, свят и образен. Очень часто можно слышать от несведущих людей такие примерно рассуждения: « В Библии говорится о Небесной тверди. Но мы-то знаем, что небо - это воздух, а воздух не твердый. Следовательно, священный текст неточен». Ну, почему мы понимаем все так примитивно? В данном случае речь идет о твердости как о постоянстве. В самом деле, небо, Царствие Небесное постоянны, это, можно сказать, мировая константа. В этом и заключается смысл понятия «твердь небесная». Надо так же понимать, что слова «страдание» и «радость» по сути своей - однокоренные. «Ра» и «стра». В обоих этих словах буква «т»- не что 
иное, как образ креста. А в тенгрианстве крест имеет т-образную форму. Радуясь, следует помнить, ценой каких страданий дана нам эта радость. А страдая, надо терпеть, помня, что за страданием следует избавление. В текстах священного писания состояние радости упоминается почти восемьсот раз, как стабильное чувство, а счастье, как переходящее, сиюминутное «сейчас» упоминается в священном писании лишь двенадцать раз. А название икон. Представьте себе такую икону «всех скорбящих счастье» или « нечаянное счастье» - нелепо, не правда ли? Куда привычнее, понятнее и логически обоснованней - «всех скорбящих радость», «нечаянная радость». И, взывая к Богородице, мы поём: «Радуйся, Благодатная...», а не призываем Ёе быть счастливой. Стыд - студ, то есть холод. Человек испытывает от стыда такой же дискомфорт как от стужи. Да и глубокое, практически нелитературное слово «мразь» означает тот же холод, мороз. Отсюда вполне логично напрашивается вывод, что слова «стыд», «смрад», «мразь» - слова одного порядка, ассоциирующие с адом - местом, удаленным от Бога. Эти примеры еще раз 
подтверждают справедливость высказывания Владимира Короненко: «слово не есть мертвое и внешнее зеркало, оно есть в то же время орудие ЖИВОГО, движущегося, совершенствующегося духа, оно есть орудие совершенствования». Вот еще интересная взаимосвязь: Каин и произошедшие от его имени «окаянный», «окаянство», т.е. охваченный, обуреваемый страстями Каина. «Покаяние» - осознание своих ошибок и нежелание продолжать греховную жизнь. Если внимательно проанализировать речевые конструкции церковнославянского языка, то выясняется, что он весьма образен. Очень многие слова и словосочетания его является идеальными, то есть либо непереводимыми буквально на другой язык, либо теряющими при переводе изначальный смысл, мелодичность звучания и образность. Попробуем сравнить некоторые слова церковнославянского языка их английских аналогов. И сразу бросится в глаза, как неуклюже, а порой и нелепо звучат знакомые нам с детства слова на иностранном, в данном случае, английском языке. Благая весть в английской интерпретации имеет вид «the good news» - хорошие новости. Отсюда и 
Благовест будет звучать как «ringing of one church bell» - звон (звучание) одного церковного колокола. А Преображение переводится как «transfiguration», т.e. трансфигурация. Нелепо по сути своей. Этак, можно Создателя представить в виде такого трансформера, как детскую игрушку. Вот уж действительно язык мой - враг мой. В русском языке, как ни в каком другом, постоянно усматривается логическая связь речи, слова с Богом, с божественным проявлением. Так, например, в английском языке отсутствие людей (в помещении, на территории и т.п.) будет иметь конструктивную форму «nobody», то есть «нет тела». Этим подчеркивается физическое отсутствие объекта в данном месте в данное время. В русском же языке есть образное выражение «ни души». И здесь речь идет уже о душе, как божьем творении, о бессмертной человеческой душе. Обратимся к тексту священного писания: «И сотворил Бог человека по образу своему, по образу Божию сотворил мужчину и женщину. Мужчина и женщина как одно целое, как две ипостаси одного объекта, две половины. Итак, половина от одного объекта дает такое понятие, как 
половая принадлежность. Пол - половина. Одна половина (один пол) - мужчины, другая женщины. Иными словами, две половины мужчина и женщина по воле Божьей в человеке сливаются в один объект. Во многих языках: немецком (mann), английском (men), в тюрских языках (одам), в малороссийском (чоловік) мужчина - понятие, тождественное понятию «человек». В то же время пол, как часть помещения (противоположного потолку) также от половины. В древности при строительстве бревна распускали вдоль и укладывали рядом плоской стороной вверх. Таким образом, пол от половины бревна.

Каждый из нас старается достичь в жизни определенной цели. Проанализируем взаимосвязи в словах «цель», «прицел», «прицеливание», «целенаправленный», «целое», «целина», «целковый» (старинная монета), «поцелуй». Во всех этих словах четко просматривается корень - цель (целостный). Духовная, телесная цельность, целостность, извечное стремление к ней - в этом, по большому счету, выражается высшая цель, целеустремленность. И поцелуй призывает к единению, целостности двух половин одной человеческой плоскости. Известное слово 
«невеста»

опосредованно,

через

старославянский язык уходит корнями в санскрит. Здесь уже упоминавшийся ранее корень «вед» (вест, весть), т.е. знание, известность (об объекте) и т.п. Можно привести две трактовки этимологии этого слова «невесть»: неизвестная, незнакомая.

Действительно, входящая в семью будущего мужа (жениха) неизвестна в полной мере для новых родственников - невесть, неведение, незнание греха. В данном случае символ чистоты и непорочности. А вот те, кто познал темную сторону жизни (грех), тех именовали ведуньями или, еще того хуже, ведьмами. Близко по значению к ведунам и ведуньям и слово искусство. Корень здесь «искус»- то есть искушение. Необходимость познать и изобразить, выставить напоказ сокровенные, интимные, порой греховные стороны человеческой души - весьма опасна. Очень легко поддаться искушению. И многие актеры, увы, пошли по наклонной дорожке, ибо велик соблазн. Многих сгубило пристрастие к алкоголю, у многих так и не сложилось прочных семейных отношений. Недаром театральное (балаганное) зрелище в старину называли словом позор, то есть выставление на просмотр (позор) публики сокровенных уголков 
чужой души. Сакральный смысл имеют и слова управитель, управляющий, правитель, право. Правитель - лицо, которому предназначено вести свой народ по правому (законному, определенному Богом, - «правь») пути. Намного образнее и емче всяких генсеков, вождей, президентов и иже с ними. Именно потому, что сам язык русский имеет божественные корни, и в душе истинно русского человека Бог, а не доллар - Христос в душах у нас. Поэтому для Европы, которая рабыня Христа, душа русская есть загадка, как и сам Христос. Потому и не любят нас ни в США, ни в Европе. Прав был Тютчев. Умом практичного, приземленного европейца, пересчитывающего свои франки, марки, евро, Россию постичь нельзя. В неё, как и в Бога, можно только верить. В послании святого апостола Павла к Римлянам сказано: «... Вера от слышания, а слышание от слова Божия» $[17,10,17]$. И опять просматривается взаимосвязь - наука означает на ухо, то есть «слышание». Действительно, умение слушать очень важно для человека. Получается, что каждое слово языка нашего родного содержит хоть маленькую крупицу чуда. А чудо от чути, то есть «слышание». В малороссийском языке так и говорят: чуешь? - то есть - слышишь? 
Доктор филологических наук, профессор В.Ю. Троицкий, так высказался о русском языке: «Мы обязаны знать, что русский язык душа России, её святыня, предметное воплощение высших духовных ценностей, нерушимое духовное достояние, без которого человек (и народ!) теряет свое лицо, при поругании которого народ испытывает ущерб своему достоинству и духовной самостоятельности, оттесняется, становится нравственно уязвимым и духовно бессильным. Мы как зеницу ока должны беречь родное слово. Слово дано для стремления к истине. Судьба наша - в словах, нами произносимых.

\section{ГЛАВА V. ЯЗЫК КАК СОСТАВЛЯЮЩАЯ НАРОДНОГО БЫТИЯ.}

Русская литература, языковая культура это неотъемлемые составляющие нашей ментальности, нашей духовной сущности. Можно сказать, язык есть та духовная среда, в которой обитает народ. С другой стороны, язык русский выступает коммуникативным атрибутом, средством национального единения и взаимообогащения культур всех народов России. И язык, как великое сокровище, как 
святыню следует тщательно оберегать и заботится о его развитии. Ведь исторический факт создания славянской азбуки и, будем говорить, конструктивной структуры языка нашего святыми апостолами уже никто не оспаривает. Значит это действительно язык освященный искрой Божьей, не имеющий аналогов среди других языков. Неспроста ведь наши великие соотечественники проявили неустанную бдительность в деле сбережения и приумножения русского языка. Вспомним Тургенева и его откровения по поводу русского языка, рожденные «во дни сомнений, во дни тягостных раздумий...». Или И.А. Бунина, который в преддверии драматических революционных событий писал: «Умейте же беречь хоть в меру сил, в дни злобы и страдания, наш дар бессмертный - речь». Вспомним «звучащий как колокол на башне вечевой» русский язык в стихах М.Ю. Лермонтова. Как проникновенно и призывно звучат стихи А.Ахматовой, написанные в 1942г. в Ленинграде: «Мы сохраним тебя, русская речь, великое русское слово. Свободным и чистым тебя пронесем, и внукам дадим, и от плена спасем». И возвращаясь к Тургеневу, так и хочется сказать: «Как не впасть в отчаяние при виде того, что совершается дома с русским 
языком сегодня». Сокровищница русского языка, этот священный Грааль переполнен словесной шелухой, зловонным мусором. Словно никогда не жили на нашей благословенной и многострадальной земле В. Даль, М.Ломоносов, Ф.Достоевский, М.Шолохов, А.Чехов. Как ни прискорбно это звучит, но когда слышишь речь современного среднестатистического россиянина, возникают ассоциации с замечательной книгой И. Ильфа и Е.Петрова «Двенадцать стульев» и её героиней Людоедкой - Эллочкой. Надо твердо усвоить, что преодоление обилия кризисных явлений нынешнего периода нашей отечественной истории невозможно без духовно нравственного возрождения общества, без опоры на русскую культуру и культуру всех народов нашей отчизны. $\mathrm{K}$ сожалению, пошлость, невежество, духовное и языковое бескультурье - опасные приметы нашего времени. Основной вклад в снижение и падение общего культурного уровня внесла так называемая рыночная экономика, коммерциализация с их пагубными и вовсе неприемлемыми для нашей культуры законами. Рынок, да и вообще экономика - чуждые для нас социальные явления, навязанные нам Западом. Именно это стало основным препятствием для 
полномасштабного и свободного развития и процветания классической национальной культуры. Произошла подмена ценностей. Особый изощренный вред наносит нашей культуре массовое внедрение в нашу речь ненормативной лексики. Причем, что обидно, нецензурщина сегодня звучит из уст писателей, артистов, которые должны стоять на страже чистоты языка. Примитивный уровень языка поддерживается либеральным крылом. Все эти либерализмы и демократизмы генетически не наши, не российские. Необходимо и на политическом уровне бороться за чистоту русского языка. В этих целях необходимо разработать правительственную программу по охране и сбережению русского языка. Данная программа должна предусматривать:

- ввод уголовной ответственности за сквернословие, предполагающей штрафы до 100 тыс. рублей или исправительные работы до 240 часов;

- установление цензуры на государственном уровне, не обращая внимания на европейский визг о свободе слова;

- ввод уголовной ответственности за противодействие сохранению и защите русского языка как символа государственности; 
- увеличение количества часов русского языка и литературы во всех учебных заведениях, независимо от их профиля, и возвращение в обиход такого названия как «словесность» вместо литературы, поскольку «словесность» понятие более емкое и лучше отражает задачи образовательного процесса;

- создание государственной комиссии по контролю над языковой культурой средств массовой информации;

- увеличение количества часов, отводимых на цикл гуманитарных дисциплин во всех технических вузах, что в целом повысит престиж инженерного образования;

- возвращение в паспорта графы «национальность», что соответствует Божьему промыслу в государственном устроении.

Несмотря на сложные времена, на серьезные коллизии в международных отношениях, несмотря на чиновничий произвол, засилье некомпетентных работников сверху донизу, несмотря на трудное материальное положение большинства населения нашей страны, Россия живет Верой, Любовью и Надеждой. И порой маяком и спасительным плотом в этом бурном житейском море является 
русский язык. Познав суть языка и раскрыв его тайны, мы, возможно, найдем ответы на многие вопросы. Автор настоящего исследования, являющийся членом Союза писателей «Многонациональный Санкт-Петербург» и имеющий в своем творческом багаже шесть поэтических сборников, посвящает русскому языку следующие стихи:

Тайна русского языка

Я тайну силился понять,

Загадочность родного слова.

Бежало молча время вспять,

Хотя по сути, все не ново.

Оно ведь с детства мне знакомо,

Впиталось вместе с молоком.

Но, тайной странного влекомый,

Я с ним, как будто, незнаком.

Родной язык,- вся суть моя,

Заключена в его лексемах.

Смысл проявленья бытия,

Как икс и игрек в теоремах.

О буди, Боже, буди мне

Ты милосерд, великодушен.

Не попали меня в огне,

Не дай пропасть заблудшим душам.

Лампады огонёк горит, 


\section{И книга Божьих откровений, Раскрытой на столе лежит. \\ Молюсь я, преклонив колени...}

Будем же беречь и приумножать сокровищницу русского языка, каждый на своем месте и все вместе на благо нашей России.

Язык формирует то понимание, которое человек получает с детских лет в процессе обучения как стартовую площадку для первичного осмысления картины мира. В дальнейшем в ходе использования языка (в процессе языковой социализации) формируются личностные качества и групповая идентичность, вырабатывается мировоззренческая позиция. В целях формирования национального самосознания, приумножения языковой культуры и самобытности русского языка настоящее исследование включает в себя словарь церковнославянского языка. Данный словарь способствует познанию многогранности русского языка, как отечественным читателем, так и иностранцем, интересующимся проблемами славистики и, в частности, русским языком. Кроме того данный словарь поможет 
понимать тексты священного писания и смысл православного Богослужения. К словарю прилагается также церковнославянский алфавит и таблица чисел. 
СЛОВАРЬ ЦЕРКОВНО-СЛАВЯНСКИХ СЛОВ И ВЫРАЖЕНИЙ

\section{A}

Абие

вдруг, немедленно, тотчас, сразу. Отсюда поговорки: «Если бы, да кабы» - т.е. если вдруг или сразу произойдет.

A3 я (и первая буква славянской азбуки).

Акафист

хвалебная песнь. Переводится $\mathrm{c}$ греческого как «Неседальный» т.е. во время чтения акафиста положено стоять. Сидеть дозволяется только немощным и болящим. Акафист состоит из 13 кондаков и икосов, один кондак поется и 12 кондаксов и икосов читаются.

Аллилуиа

(аллилуйя) славите Бога, Хвалите Бога, пойте хвалебные песни.

Аминь (на латыни amen)- воистину, да будет так. 
Аможе

Антифон

Аще

Аще бо

Аще убо

Бдети

Бe

Бехом

Беx

Бесте

Беша, беху

Безвестный куда, туда.

песнопение, исполняемое двумя хорами поочередно. Фон-звук, значит звучащие друг за другом (противу друга - анти).

если, ли, хотя.

если.

если же

Б

бодрствовать, не спать. Отсюда - бдительность, бдительный.

он был, она была, оно было.

мы были.

я был, была.

вы были.

они были.

неведомый, неизвестный. Не подающий весть (опять усматривается корень «вед» (вест)). 
Безгодие

Безместный неблагоприятное время.

неуместный, неприличный, непристойный.

Безприкладный

безпримерный. Так, в малороссийском языке до сих пор существует - неприклад например.

Благоволити

изъявить милость, добро, любовь. Дословно - проявить благую (хорошую, добрую) волю.

Благостыня добро.

Блаже

благой, добрый (звательный падеж).

Благожити прославлять, восхвалять, славить.

Бо ибо, потому что. Данисея форма сохранена малороссийском языке.

Боголепно 
Богородичен

краткая

молитва

(молитвословие)

B

честь

Божьей матери.

Брань

война.

Буди

будь.

Бысть

он был, она была, оно было.

Бых

я был, была.

Быхом

мы были.

Бысте

вы были.

Беша

они были.

Бяще

он был.

Бяху

они были.

B

Ваия

древесные (пальмовые) ветви. На вербное воскресенье при освящении веточек вербы произглашается:

ce освящается вайя сия во имя Отца и Сына, и святаго духа.

Bap

сын (еврейск). Отсюда варнак, так же и солнечный жар, зной. Мы и сейчас говорим: «жарко 
- свариться можно», отсюда глаголы варить, сваривать, варево и т.д.

Варвар

чужеземец, незнакомец, не наш, чужой. Отсюда имя Варвара и Ваевара в Европейских странах.

Варити предварять, преддверие, упреждать, и (варяти) встречать.

Василиск

Вельзевул диавол.

Вельфегор Мравитский идол.

Вежда

Велелепота красота).

Велий, Велия великий, великая.

Волицей

Вельми

Вем

Веси великой.

весьма, очень.

знаю.

ты знаешь. змея (змей).

Аккаронский идол, бес, веко, глаз.

великолепие

(большая 
Весь

Вепрь

Верея

Вертеп

Вертоградарь

Вития

Взыграти

Взимати

Вина

Виссон

В книзе

животней

Вкупе село (населенный пункт)

дикий кабан.

столб от ворот.

пещера.

садовник

оратор, проповедник.

возвеселиться, возрадоваться, разыграться.

B

малороссийском языке грашка

- игрушка, грашки - игрушки.

отнимать, забирать.

причина, извинение.

драгоценная, тонкая и мягкая льняная ткань, дорогая одежда пурпурного цвета.

в книге жизни.

вместе, совместно. Отсюда купе-помещение, где находятся вместе (люди) купе железнодорожного вагона, вещи - шкаф - купе. 
Владыяце

Вмале

Вменити

Внегда

Внушити

Во еже

Вои

Bо3

Возвергати

Возбраняти

Возгаратися

Возгарается

нищий

Возглядати владыке.

вскоре, едва.

приписать, поставить во что, подумать. Отсюда: вменяется в вину, вменяемость, невменяемый.

когда.

внять, услышать.

чтобы.

воины, войско.

вместо,

$3 a$.

Отсюда:

возместить, возмездие,

воздание.

полагать.

препятствовать, удерживать. Отсюда: оборона и малороссийское заборонено запрещено.

загораться, загореться.

гонится, преследуется нищий.

смотреть. 
Воздети

поднять. Аз воздержу - я подниму.

Вознепшевати подумать, предложить.

Возриновен поколеблен, потрясен.

Волна шерсть.

В оньже в который.

В пложе в воторую.

В няже в которые.

Воня аромат, запах, благоувание. В современном русском языке вонь - плохой, неприятный, тошнотворный запах.

Вотще напрасно. Отсюда - тщета, тщетно - бесполезно, безрезультатно.

Восклонение ложе (куда склоняют голову), успокоение.

Воутрие

на другой день (утром).

Вресноту

действительно, подлинно.

Вретище

одежда из грубого холста.

Вскую

для чего, зачем. 
Вспять

В страсе

Bcye

Всяческая

Выну

Выспрь

Выспорный

Выя

Вязати

Вящще

Гаждение

Ганание изречение.

Глас

Глумиться размышлять.

Гобзование назад.

в страхе.

$$
\text { напрасно }
$$

(поскольку совершается в житейской суете).

все, весь мир, вселенная.

всегда.

Bвepx.

идущий вверх.

шея.

не прощать, связывать.

больше.

$$
\Gamma
$$

порицание, хула.

гадание, загадка, краткое голос. забавляться, насмехаться; изобилие, многоплодие. 
Гобзовати

быть богатым, надменным, изобиловать, способствовать обилию, умножить обилие.

Аз гобзую я богат, надменен, умножаю обилие.

Гобзуяй счастливый, радующийся.

Гope вверх.

Гopee превыше, хуже (горше) отсюда горе, горевать.

Горохищное заблудившиеся в горах.

Господеви Господу.

Гресе грех.

Гугнивый заика, косноязычный.

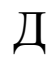

Да бых аз что бы я, наконец, прекратил. етсене престал

Даск ты дашь.

Двоя дважды.

Деля для. 
Денница

Десный

Десница

Дебрь

Детель

Дивий

Днесь

Доброгласный

Доброта

Довлеет

Догматик утренняя заря, луг зари, начальник падших ангелов, названный так по своим достоинствам и блестящим совершенствам, какими он был первоначально наделен Богом. Возгордившись, и посчитав себя выше Бога, стал падшим ангелом (бесом). правый.

правая рука. лес дубрава (дебри, заросли). дело, деятельность, деятель. дикий. сегодня, сейчас.

имеющий приятный голос. добрые качества, красота. достаточно. Да довлеет пусть будет достаточно.

песнь в честь Богородицы, содержащая догматическое 
учение сына Божия Иисусе Христе.

Доколе лолго ли, как доло.

Доле (долу) вниз, внизу, в преисподней.

Должникомдолжникам.

Донеже до тех пор, пока.

Древле когда-то, некогда, отсюда древность, древний, в древности.

Дрождие дрожжи.

Душе дух (звательная форма).

Дщерь дочь

E

$\mathrm{E}$

оно, его (им. и вин. падеж ср. род. ед. число)

Егда

в то время как, когда.

Егоже которого (род. и вин. падеж м.р и род. пад. ср.р ед.ч)

Еда неужели, разве, ли.

Еда како чтобы не. 
Еже

которое ( им. и вин. падеж ср.

p. ед.ч), еже при глаголе в неопределенной форме чтобы. В некоторых случае еже не переводится на современный язык, например, «воспеваем еже радуйся» воспеваем: радуйся. Можно в данном случае сравнить с неопределенным артиклем в английском.

Ей

да. Близко по звучанию к английскому yes, немецкому уа, тюрскому - ю.

Елей оливковое масло.

Елень олень.

Еликий

сколький.

Елико

как, сколько.

Елицы

те, которые.

Еммануин

с нами Бог - такое обозначение дал пророк Исайя Иисусу Христу.

Евродий аист, цапля, журавль. 
Еси

Есмь

Ехидна

Жаждати

Живой

Жребодание

Жрети

Жупел

смола.

ты есть.

я есть.

ядовитая змея.

\section{Ж}

сильно желать (хотеть).

жизнь.

разделение по жребию.

приносить жертву Богу.

Отсюда - так же пожрети -

пожрати - жертвоприношение (поедание жертвенного).

Отсюда просторечие - жрить, пожрать сожрать - пронимать пищу. Обожраться - переесть.

адская мука, горящая сера,

3

Законоположити указывать путь закона, наставлять, создовать законы.

Закоснети замедлить, упорствовать в своих привычках. 
Закров

Зане, занеже как.

Запнути

Запяти

Запяти пути.

Заутро

Заяти

Звание

Зде

Здо, на здех

Зелие

Зело завеса, покров, отсюда закрыть, закрывать и т.п.

ибо, потому, потому что, так воспрепятствовать.

запинать, препятствовать.

поколебить стопы, сбить с

рано утром. Отсюда - завтра, на следующее утро, следующий день.

взять в долг (взаймы).

вопль, зов, крик. Отсюда современное словосочетание воинское звание. То есть, как называть (звать) человека, имеющего определенные знаки различия на мундире.

здесь.

кровля.

зелень, трава, лекарство, яд.

много, очень сильно. 
Зельный

Зеница

Зиждемый

Людне

зиждемии

Знаемый

Зобати $30 б$.

Зрак

Зря

И

Идеже

Иерей

Иже

Извествовати

Изволити

Известно глубокий, сильный.

зрачок.

создоваемый, устроенный

будущее поколение.

знакомый. В малороссийском языке знаёмый - знакомый.

клевать, т.е. - класть пищу в

вид, образ, лицо.

видя.

\section{И}

его, их, они (им. и вин. пад. м.р. ед.ч. им. пад. м.р мн.ч)

где, там.

священник.

которые, который, кто, тот, те.

удостоверять, утверждать.

Отсюда известие, известность. избрать, предпочесть.

наверно, твердо. 
Извититствовати красноречиво говорить, витийствовать.

Изженати

Измена

Изощряти

Изрядно

Изсхнути

Иисус

Имже

Имя рек

имя

Имети

Имам

Ин

Иногда
Выгонять, изгонять. В малороссийском языке изженить - прогнать, выженять - выгонять.

выкуп, обмен.

заострять.

особенно.

сохнуть

спаситель.

тем, которым (тв. пад. ед. ч. м.и ср. род. дат.пад. мн.ч.)

назови имя, назвав (сказав)

иметь

я имею

другой (иной)

когда-то, некогда. В современной интерпретации нечасто, не каждый раз. 
Ископати

Искони

Исперва

Исповедание

Иссоп

Истаяти

Истление

Истнити

Аз истно

Истощати

Исходише

выкопать (откопать)

издревле

из древности

открытое признание.

травянистое растение, из веток которого в древности делались кропила, «окропише мя иссопом и очищуся» в наши дни произрастает практически на всей территории России как садовое растение. Заваривают в качестве чая, добавляют в салаты. Имеет целебные свойства.

истончать.

тление, опустошение, погибель, порча, разрушение. истоптать, сломать, стареть. я истопчу, сломаю, сотру. опустошать, разрушать. источник, распутье 
Исчадие

Ихже

Камо

Кандило

Канон

Касия

Кафизма

Кивот плод чрева.

которых.

K

куда

лампада

песнопение в честь праздника или святого, составленное по определенному правилу. Содержит девять песен. Учитывая, что вторая песнь опускается, можно говорить о восьми песнях. Она бывает в великопостных канонах. Каждая песнь состоит из ирмоса и составленных по его образцу тропарей.

дикая корица.

чтение из Псалтири, во время которого разрешается сидеть.

Ковчег Завета - особый ящик, в котором хранились скрижали Завета и другие ветхозаветные святыни. 
Кийждо, каждый, каждая, каждое.

каяждо, коеждо

Комуждо

каждому.

Кимвал

музыкальный, ударный инструмент, состоящий из двух медных кружков.

Употреблялся B иерусалимском храме во время праздничных богослужений.

Кимин

Клеть

Книжник

Ков

Коегождо

Колесница

гонитель

Коло

Колькраты
ТМИН.

комната.

ученый человек.

умысел, заговор. Отсюда выражение строить ковы, значит, организовать заговор, осуществить злой умысел.

каждого.

правящий колесницей.

колесо, круг.

сколько раз. 
Кноб

Коснети

(коснити)

Косно

Котва

Кошка

якорей.

Крастель

Крин

Кроме

Кромешный

Кротость

Ктому

Купина

Кустодия

Куща

Ланита

Лентион горшок, котел, лохань.

медлить.

медленно.

якорь.

один из видов корабельных

корастель, перепел.

лахия.

BHe.

внешний, наружный.

кротость, смирение, слабость.

сверх того.

куст, кустарник.

стража.

палатка (евр.).

$$
\text { Л }
$$

щека.

полотенце от греч. «лента» длинный кусок ткани. 
Лепета

Лепта

Лесть

Лива, Лив

Лик

(ликование).

Лихва

обман.

Лишше

Ловитва

охота.

Ловительство

Лож

Лукавое

Ласто

Лядвь красота, великолепие.

самая мелкая медная монета.

Отсюда выражение - внести свою лепту.

обман.

Юг, Южный.

пение,

xop

B xpame

дитя, прибыль, рост, взятка, больше, сверх того.

звериная ловля, добыча, засада, охота.

ложный.

злое, коварное.

голени, лодыжки.

бедро, поясничные мышцы, жгучая, мучительная боль. (мн. Число лядвия) 


\section{M}

Мамона

Масть

благовония.

Междорамие м междуплечие, спина.

(рамена - илеги)

Мерило

Мертвые века

Мессия

Местник

отомститель.

Месть

Mex

Мильть

плащ.

Мир (мирь) согласие, тишина, мир - весь мир человеческий.

Мышца

Многочастие

Мося богатство, земные блага.

жир, тук, масть, мазь, давно умершие.

помазанник.

мститель,

Злобный,

возмездие, мщение, справедливое наказание.

мешок.

верхняя шерстяная одежда,

сила, плечо.

много раз.

моей. 
Моя

Мрежа

Муж кровей

Мшельимство

Мя

Назирати

Назнаменуя

Наипаче

Наказание

Наказуя

Наляцати

Нань

Напрасно

Нашея

Наяти

Невечерний вечный. свет

Неистовление

Неключимый мой.

невод, рыболовная сеть.

кровожадный человек.

корыстолюбие.

меня.

\section{$\mathrm{H}$}

наблюдать.

давая понять.

особенно же.

вразумление, научение.

поучая.

напрягать.

на него.

внезапно.

нашей.

нанять.

всегда светлый, незаходящий,

бешенство.

негодный, недостойный. 
Не ктому

Не леть

подобает.

Неплодов

Неподобный

Ненщевати придумывать.

\section{Аз непщевах \\ придумываю.}

Несекомый

камень.

Несть

Несытный

Неудобь

Неделя

Не к тому более не

невозможно, нельзя не

неплодство,

замужняя, бездетная женщина.

неподобный, недостойный, непристойный.

думать,

рассуждать,

я думаю, рассуждаю,

крепкий, твердый, гранит, не есть.

алчный, надменный.

трудно.

воскресный день, когда не делают обычных работ (не делать). В малороссийском языке - недиля - воскресение. уже не. 
Ниже

Николиже

Ниц

Ничтоже

Ничтоже велие

Ничтоже дивно

Нощный вран

Нощное

поприще

Нудиться

Ны

Ныне

Нырище

Обавати

Оба полы

Обаче и не, и ни (даже) ни, а только, так же не.

никогда.

лицом вниз.

ничего, ничто.

ничего особенного.

ничего удивительного.

сова, филин.

время ноги.

добываться с трудом.

нас.

теперь.

развалины

$\mathrm{O}$

внушать, врачевать, заклинать, заговаривать.

с обеих сторон.

впрочем, но, однако. 
Обветшавате

одряхлеть,

обессилеть,

обветшать. (обетшати)

Обвиноватися колебаться, сомневаться.

Обдержание обладатное, управление.

Одержати овладевать, порабощать.

Обесити повесить, висеть.

Обоюду по обе стороны, с обеих

сторон.

Обинутися отступить от чего либо.

Не обинутися смело поступать, не отступать.

Аз обинюся я отступлю от чего-либо.

Обладати обладать.

Облазжети соблазнить.

Обязати обязать, связать.

Обязуят врачующий болезни и скорби.

сокрушения

Обышедше обступить, окружить.

(обыдоша)

Овогда иногда.

Одебелети отяжелеть. 

Одержати
Одесную
Одичитрия
Одр
Озлобление
Озобити
окружать.
справа.
путеводительница.
носитель (ложе).
страдание, горе.
истреблять.

Окаянный

Окромляти

Окрест

Омет

Ометы

Онагр

Онех

Он пон

Ону

Оправдание

Орган

Осанна

слава.

бедный, злосчастный, мучитель. направляти. вокруг, около. край, кромка. края одежды. дикий осел. Tex. ту. несчастный, другая сторона (половина). заповедь, права, закон, устав. музыкальный инструмент. спаси, сохрани, спасение, 
Осетовати

Оскорд

Ослабити

Особитися

Останок

Отнодухое

Острастиший

Отдоити

Отрасль (отрок).

Отревати

Отриновен

Отрыгати

изрекать.

Ойтрясен

Отгаянный

Оцвести

Оцет оплакивать.

секира, топор,

облегчить, простить.

уединяться.

остаток, потомок.

B

малороссийском

языке

останный - последний.

откуда.

обидчик.

окончить

кормить

материнским молоком.

ветвь, отросток, отпрыск

отталкивать.

отвержен.

возвещать, извергать,

здесь, изгнан.

потерявший всякую надежду. покрыться цветами. виноградный уксус. 
Очервленный окрашенный в багряный цвет.

Очима двумя глазами.

Ошую слева.

$\Pi$

Падажь

ров, падение, разрушение.

Пазнокть

ноготь, коготь, копыто.

Пали

еще, опять, снова.

Палица

палки, посох.

Паче

более, выше, превыше, лучше.

Паучина

паутина.

Певч

вид сосны.

Перси

грудь.

Перст

палец.

Персть

земля, прах.

Пискати

играть на дудке.

Пленицы

сети.

Плещи

плечи.

Плесна

подошва, плесна

Поведти

объявить, рассказать. 
Погибох

Погладити

Поглумиться

Погнати

Аз пожену

Подаси

Подражнение

Подвигатися

Поженити

Пожрети жертву.

Пожру

Позор

Ползкий

Полма мающий).

Полуденный я погибох.

выровнять, расширять.

издеваться, насмехаться, рассуждать, размышлять.

погнаться, преследовать, прогнать, сопровождать.

я погонюсь, преследую, прогоню, сопровожу.

ты подашь.

осмеяние.

колебаться.

изгнать.

проглотить,

принести

я принесу жертву.

зрелище.

скользкий.

пополам

(имеющий,

бывающий с полдень. 
Польский

полевой, земной, в отличие от водного.

Помивати дать знак руками или глазами.

Помизати мигать, подмигивать.

Помози помоги.

Поне хотя, по крайней мере.

Понос поношение, бесчестие.

Понт Mope.

Попрати сокрушить.

Потерпети надеяться.

Прадедний прародительский.

Превыспренный возвышенный, расположенный высоко, находиться выше всего.

Превратити изменить.

Предварити предупредить, стать или сделать раньше.

Предстояй предстоящий.

Презирати не смотреть, не предавать значения, не замечать. 
Прелесть обольщение (по сути, лесть в превосходной степени).

Преложение тень, легкое подобие непостоянства. (осенение)

Пременение перемена, изменчивость.

Преподобный святой, праведный.

Препоновитки достигнуть половины установленного срока.

Пререкание возмущение.

Преселиться отойти, переселиться.

Прибежище приют, покров.

Привитати обижать, жить.

Привменен уподоблен.

Призирати смотреть, быть милостивым.

Приложитися присоединиться.

Приметатися припадать, лежать у порога.

Приникнути наклониться.

Приседати участвовать.

Присно всегда.

Причастник участник. 
Пришельствовати

пришельцем, странствовать.

продолжить, продлить,
Пробивити сохранить.

Продябати

Просвещаяй

Прости

Простый

Пруг

Пря

Псалом

Псаломский

Псалтырь произрастать.

просвещающий.

станем прямо, благоговатно.

прямой, правый.

саранча. (мн. число прузи)

спор, ссора, тяжба.

священная песнь Псалтири.

относящийся к толпам.

десятиструнный музыкальный инструмент, под звуки которого пелись псалмы. А так же книга священного писания, содержащая псалмы.

Путе сотворити открыть, приготовить путь.

Путы оковы.

Пядь мера длины, расстояние между расставленными 
большим и указательным пальцами.

\section{$\mathrm{P}$}

Равнодушный единодушный.

Разботети подняться, стать плодоносным.

Разве

Развратитеся разгневаться, карать.

Разрешати

Рамен, рамы

Растлити

Рекл еси

Pex

Ров, ровенник

Рог

сила.

Рожогный

Розга

Ругатися

Рукама развязывать.

терновник.

погубить.

ты сказал.

я сказал.

ров, яма.

гог ,крепость, могущество,

роговой, из рога.

ветвь, побег.

насмехаться, играть.

двумя руками. 
Рукоять

Руно

Руще

Рцом

Саваоф

Свадих

Свидение

Свободи

$\mathrm{Ce}$

языке це, в

Се бо

Село

Седмица

Сельный

Село рукоять, овсянка, сноп (то, что берет рука жнущего).

шерсть, овчина.

руки.

мы изречем, скажем.

C

бог сил.

я ссорился.

откровение, свидетельство. Позже интерпретировалось в свидание (свидеться).

свободный.

вот, это. В малороссийском английском The.

ибо вот.

поле (то есть там, где сеют. Затем населенный пункт, где селятся).

семь дней недели.

полевой.

сюда. 
Сене

Сечиво

Сеча друг друга.

Сея

Сице

Скимен

Скиния

Скнипа

Скорпия насекомое.

Скотен

Скоты польския

Скраний

Скудель

Слана

Сланость

Служба

Слящися

Аз слякохся сень.

секира, топор.

сражение, где войны рубят

этой.

так

львенок, молодой лев.

палатка, шатер

вошь.

скорпион,

ядовитое

подобный скоту.

звери полевые.

Висок.

глина, черепок.

иней.

соленость, соленый вкус.

употребление.

сгорбиться, согнуться.

я сгорблюсь, согнусь. 
Смирич

мирро,

смолистое

вещество.

Снабдети

Снедное

Снести

Сокрушение

Сонм

Сотрение

Составляти

Спяти

съестное. оберечь, сохранить.

сокрушать.

иных о грехах.

собрание, судилище.

разрушение.

сооружать.

опрокинуть, повергнуть.

Отсюда выражение снятыть, снятил - лишится рассудка, сошел с ума, - все ломает.

встреча.

встреча, несчастье, зараза сосущий (о младенце).

благовонная смола, калия, ладан, тончайший вид смирны, благовонная жидкость из смирны - духи. 
Стезя путников.

Степени

Стицатися

Стогна

Столп

Столиописание

Стражба

Странна

Странно

Страсть

Стрыти

Студ

Студный

Студенец

Студенец истления тропа, узкая дорога для ступень. собираться. улица, площадь. столб, сторожевая башня. всенародное объявление. стража, время между двумя сменами стражи.

непричастна таинственно, необъяснимо. страдание.

сокрушать, стирать. Отсюда просторечие - стирать украсть, утащить.

стыд , поругание.

постыдный.

колодец, родник.

ров погибели. 
Стужа

холод.

Улавливается

взаимосвязь.

От

стыда

человек дрожит как от мороза.

Студием называют сегодня блюдо - холодец (мясо в застывшем бульоне).

Стужати притеснять, угнетать.

Судьба определение, закон.

Сушило хворост, сухие ветки, сухое дерево

Сый

Ся

Тай

Тать

Таяжда

Твоея

Твердь

Тебе

Теку сущий

себя

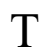

тайно.

вор.

то же самое.

твоей.

твердое основание.

тебя, тебе.

бегу. В малороссийском языке тикать - убегать, удержать. 
Активно используется это слово и в просторечии русского языка.

Тем, темже поэтому.

Терпети терпеть, надеяться, уповать.

Тещи течь, бежать (о времени, воде).

Ти тебе(дат.пад. ед.ч)

Тимпан бубе.

Тимение тина, грязь.

Тля, тление порча, разрушение, первородный грех.

Тима тьма, мрак, числительное десять тысяч. Отсюда темник $-$ военачальник, командующий десятью тысячами воинов, и фамилия Темников, часто встречающаяся среди потомственных военных.

Токмо только, лишь только.

Толико столько. 
Точило

место

для

выжимки

винограда.

Точию

только.

Тощий

пустой, тщетный.

Тощно

усердно.

Тоя

той.

Требую

я нуждаюсь.

Тросный

тростниковый.

Труд

усердие, болезнь.

Tpyc

землетрясение.

Туга

печаль, уныние.

Тук

жир.

Тук пшеничный

лучшая пшеница.

Тул

колчан

Туне

даром, безвозмездно, зря, напрасно. Отсюда тунеядец дармоед (т.е. едящий даром, бесплатно, не заработав)

Тщи ни с чем.

Тыя Te. 
Тяжести

Тяжкий

тяжцый).

Тяжкосердый

Ублажати

Убо

следовательно.

Углебати

Угобзиться

плодородным.

Удесы

члены тела.

Удоль (Юдоль) долина.

Уже

веревка,

Отсюда

цепь, жребий.

(разновидность) змеи - уж.

Укоснити

Умастити

Уис

дворцы.

многочисленный

(МH.Ч.

бесчувственный.

\section{$\mathrm{y}$}

прославлять.

итак,

потому,

же, увязнуть, погружаться.

обогатиться,

сделаться

название замедлить.

намазать. Сегодня в переносном смысле оплатить услугу (дать взятку). лучше. 
Унзати

Усладитися

Усрести

Уставы

стремление

Усыритися

Утреневати

Учаизати

Учинение

Ущедрити

Хананея

Хлябь

Хранилостража

Христос

Худый

Цареви

Цевница вонзать.

сделаться приятным.

встретить.

останови поток.

стать тучным, плодоносным.

с раннего утра, рано встать, делать поутру.

умножать.

определение, устроение.

милосердствовать.

\section{X}

хананеянка.

бездна, поток.

обуздание.

помазанник.

злой, плохой.

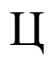

царю.

свирель, флейта. 
Церковь

общество, собрание

(прихожане), храм.

\section{Ч}

Чаю

я ожидаю

Чернигие

дикая смоковница.

Честный

достойный,

драгоценный,

дорогой.

Челновный

челюсть.

Ш

Шататися

возмущаться, волноваться.

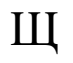

Щедрити

миловать, награждать.

Щедрота

милость.

Ю

Ю

ее. (вин.пад. ед.ч. ж.р)

Юг

южный ветер.

Юдель

долина.

Юже

которую. ( вин.пад.ед.ч.ж.р.)

Южика, ужика родственник, соотечественник. 
Юнец

Юница

Юноша

Я

ж,cp.p)

Яве

Яже

Язык

Яко

Яко еще

Яко да

Яковый

Якоже

Яти

Ям телец.

телка.

юноша, отрок.

Я

их(род.им.вин.пад.

МН.Ч.

\section{явственно.}

которая, те которые, то, что, те, которых. (им.пад. ед.ч, ж.р., им.пад. мн.ч. ср.p)

язык, народ, племя, язычники. (мн.ч. языцы)

как, так же, как, так как, что.

ибо если.

чтобы, дабы.

каковой.

как, чтобы.

схватить, взять.

я ем. 
ЦЕРКОВНО-СЛАВЯНСКАЯ АЗБУКА

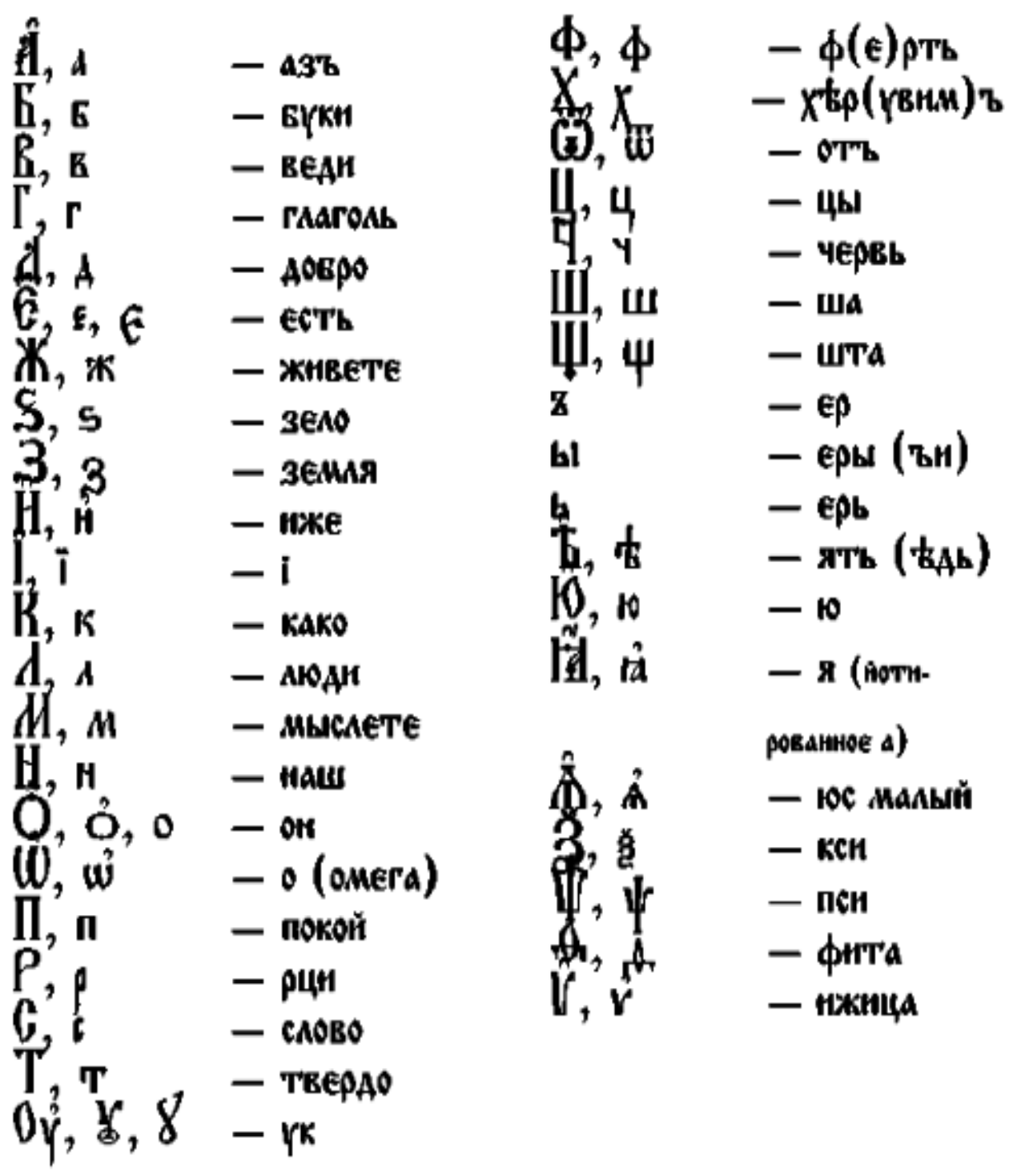


Ударения - (') острое, (') тяжелое и (') облегченное.

Придыхание - ('), этот знак может стоять вместе с ударением - (v), (').

Титло - надпись или знак над сокращенным словом. Оно бывает простое (“), или буквенное, с какою-либо из пропущенных букв (',) и др. 
Сравнительная таблица чисел

\begin{tabular}{|c|c|c|c|}
\hline Церковные & & Арабские & Римские \\
\hline A & един & 1 & 1 \\
\hline $\overrightarrow{\mathbf{B}}$ & два & 2 & II \\
\hline $\overrightarrow{\boldsymbol{r}}$ & три & 3 & III \\
\hline A & четыре & 4 & IV \\
\hline$\vec{\epsilon}$ & пять & 5 & V \\
\hline $\overrightarrow{\mathbf{S}}$ & шесть & 6 & VI \\
\hline $\overrightarrow{3}$ & седмь & 7 & VII \\
\hline$\vec{H}$ & осемь & 8 & VIII \\
\hline$\vec{\theta}$. & девять & 9 & IX \\
\hline$i$ & десять & 10 & $X$ \\
\hline$\vec{A} \hat{i}$ & единнадесять & 11 & $X I$ \\
\hline$\tilde{\mathbf{E}} \hat{\mathbf{i}}$ & дванадесять & 12 & XII \\
\hline $\overrightarrow{\Gamma i}$ & тринадесять & 13 & XIII \\
\hline$\vec{A} \hat{i}$ & четыренадесять & 14 & XIV \\
\hline$\vec{E} \hat{i}$ & пятьнадесять & 15 & $X V$ \\
\hline $\overrightarrow{s i}$ & шестьнадесять & 16 & 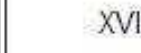 \\
\hline $\overrightarrow{3} \hat{\mathbf{i}}$ & седмьнадесять & 17 & XVI \\
\hline
\end{tabular}


Сравнительная таблица чисел

\begin{tabular}{|c|c|c|c|}
\hline Церковные & & Арабские & Римские \\
\hline$\hat{\mathrm{H}} \hat{\mathbf{i}}$ & осмьнадесять & 18 & XVIIII \\
\hline$\hat{A} \hat{i}$ & девятьнадесять & 19 & $\mathrm{XIX}$ \\
\hline$\vec{K}$ & двадесять & 20 & $x X$ \\
\hline$\vec{k} d$ & двадесять един & 21 & $X X I$ \\
\hline Ka $\mathbf{R}$ & двадесять два & 22 & XXII \\
\hline$\vec{A}$ & тридесять & 30 & $X X X$ \\
\hline$\vec{M}$ & четыредесять & 40 & $\mathrm{XL}$ \\
\hline$\vec{H}$ & пятьдесят & 50 & L \\
\hline $\bar{\xi}$ & шестьдесят & 60 & $L X$ \\
\hline$\dot{0}$ & семьдесят & 70 & $L X X$ \\
\hline$\vec{n}$ & осмьдесят & 80 & LXXX \\
\hline$\dot{y}$ & девятьдесят & 90 & $X C$ \\
\hline$\vec{p}$ & сто & 100 & C \\
\hline i & двести & 200 & $\mathrm{CC}$ \\
\hline$\ddot{\text { T }}$ & триста & 300 & $\mathrm{CCC}$ \\
\hline $\bar{v}$ & четыреста & 400 & $C D$ \\
\hline$\$$ & пятьсот & 500 & D \\
\hline$\vec{x}$ & шестьсот & 600 & DC \\
\hline$\sqrt{r}$ & седмьсот & 700 & DCC \\
\hline w & OCMLCOT & 800 & $\mathrm{DCCC}$ \\
\hline $\overrightarrow{4}$ & девятьсот & 900 & $\mathrm{CM}$ \\
\hline$\neq \hat{A}$ & тысяща & 1000 & $M$ \\
\hline$\neq \overrightarrow{\mathrm{E}}$ & две тысящи & 2000 & MM \\
\hline
\end{tabular}


ГЛАВА VI. РУССКИЙ МИР - ПЕРСПЕКТИВЫ РАЗВИТИЯ В СОВРЕМЕННОМ СОЦИУМЕ (ПО МАТЕРИАЛАМ СТАВРОПОЛЬСКОГО ФОРУМА ВСЕМИРНОГО РУССКОГО НАРОДНОГО СОБОРА).

В декабре 2013г. состоялся ставропольский Форум Всемирного Русского народного собора. В его работе приняли участие 500 экспертов из субъектов Российской Федерации и ближнего зарубежья, были аккредитованы 14 телеканалов, около 20 ничейных изданий, различные информагентства и пресс-службы. Впервые на научных мероприятиях такого уровня в качестве основы государственного строительства рассматривались такие составляющие, как нравственная и ответственная личность. Более того, впервые прозвучало, что состояние нравственности является индикатором цивилизованности и ответственности индивида перед обществом. В ходе дискуссии на форуме был озвучен целый спектр тем, но красной нитью прозвучала тема: «Русский народ: современность и перспектива». Анализ данной темы, ее обсуждение выступает для общественного сознания в качестве 
духовно-нравственной субстанции, сотканной из множества смыслов и представлений. Здесь можно наблюдать и тесное взаимопонимание, и противоречивый смысловой поток.

Положительным и обнадеживающим можно считать тот факт, что на форуме в результате рассмотрения важных и злободневных вопросов был выработан комплекс решений, рекомендаций и предложений, которые могут теоретически и практически воплотиться в современном Российском обществе. Обсуждение острых тем, спорных вопросов способствовало пониманию "болевых точек" в развитии русского мира. Главным моментом для участников форума было объявление тех позитивных моментов и факторов, которые объединяют русский народ с другими народами России. Это, прежде всего, общие победы, как на военном, так и на гражданском поприще. Следует отметить, что по смыслу и содержанию понятие «русский мир» более широкое, чем «русский народ». По данным последней переписи более $80 \%$ населения России относят себя к русским. Ведь к представителям русского мира могут быть отнесены представители любой 
национальности, воспитанные на русской культуре, впитавшие ее с детских лет, а так же представители любой национальности, принявшие православие. Исторически сложилось так, что многие известные и даже великие русские писатели, полководцы, художники, композиторы и т.д., хотя и называются русскими, этнически принадлежат другим народам. Но они представители русского мира и русские люди по своим духовным качествам. Тема России, русскости, русского народа, русского мира всегда была предметом пристального внимания и в самой России, и за ее пределами. Особенно возрастал интерес к русской тематике на крутых поворотах истории. Это войны, бунты, революции радикальные повороты от одного типа производства к другому. Здесь русский мир предстает в качестве основного бедового производственного ресурса и генератора идей и практик, объединяющих и систематизирующих духовно-нравственную жизнь народа. Сюда следует отнести язык, культуру, образование, науку, искусство, религиозные и светские традиции, принципы и нормы построения политической и общественной жизни. На этом 
фундаменте и возводится здание диалектической связи русского народа с другими этносами страны. На форуме было справедливо замечено, что многие вопросы русского мира вытекают из снижения интегрирующей роли и системообразующего начала. Важным моментом здесь является продолжающийся отток русского населения с окраин бывшего СССР. Западные специалисты предполагали, что народы Средней Азии будут отставать на сотни лет от европейских государств. В начале XX века грамотность населения Средней Азии составляла 2,6\%. За годы Советской власти республики Средней Азии стали территориями всеобщей грамотности. Русские люди ехали туда и нередко с риском для жизни выполняли свою историческую миссию - учитель, врачевали, возводили заводы, университеты. На деле так сработал так называемый эффект обратного действия. Под воздействием настроений националистического толка русские люди вынуждены были уйти из районов, ставших им малой родиной, в обустройство которой были вложены материальные и духовноинтеллектуальные ресурсы. От того, что 
русские специалисты покидают многие регионы, проигрывают все и прежде всего те, кто сознательно их оттуда вытесняет. Эта проблема сегодня очень актуальна. Почему русские для кого-то стали лишними? Эта ситуация стала складываться после распада CCCP.

Настроения эти нагнетаются не народами, a националистическими группировками, но от имени народа. Подогреваемые экстремистами страсти дают о себе знать повсеместно возникающими локальными сопровождающимися конфликтами, вооруженными столкновениями. Такие конфликты, независимо от того, развязаны они сознательно или в силу заблуждения, наносят серьезный вред всему обществу, экономическому и нравственному потенциалу России. В числе источников подобного рода конфликтов принято называть развал СССР, непродуманную национальную политику, политические происки Европы и США и российскую власть. Все это так, но на Форуме прозвучала весьма интересная мысль, а именно - причина многих негативных явлений нашего времени, в том числе и вооруженных 
межнациональных конфликтов, кроется в пренебрежительном отношении к русскому языку, к его изучению, сохранению, приумножению. Здесь и средства массовой информации, искажающие исторические факты и навязывающие населению стереотипы, чуждые нашей ментальности, поток грязной и разнузданной информации с Запада. Зачастую искажается не только история, но и сама суть русского народа. Он предстает в образе Вечно пьяного «неумехи и хулигана». Думается, пора вводить цензуру. Пресловутая "свобода слова" уже набила оскомину. Западная либеральная демократия c eе легализацией наркотиков, разврата, однополых браков и т.п. только вводит в грех. Надо как можно дальше дистанцироваться от Запада, но при этом нельзя забывать и о хитрых восточных лисицах. Нам необходимо остаться самими собой. Необходимо разъяснять, что именно под эгидой русского народа Россия из аграрной страны была преобразована в индустриальную державу, вторую в мировой экономике по своему потенциалу. Именно под Эгидой русского народа (совместно с другими) одержана победа над фашизмом. 
Сегодня русскому народу угрожает много опасностей. Единству русского народа угрожают как внешние силы, так и внутренние. На разобщение, разрушение духовнонравственного единства русского народа сегодня брошены сектантство, оккультизм, различные услуги магического характера, на которые население нашей страны тратит около двух миллиардов долларов в год. Одна из причин снижения интеллектуальнонравственного потенциала связана с тем, что многие русскоязычные специалисты, настоящие профессионалы своего дела покидают Россию и трудятся на благо других стран.

Отток русского населения снижает эффективность и региональной, и федеральной власти, а так же общественных институтов в решении важных социальных задач. Пожалуй, самый большой вопрос сегодня заключается в том, как объединить людей различных наций и народностей вокруг русского мира. Единство наций и народностей - несущая необходимость для обеспечения безопасности России. Одним из путей решения этой проблемы может стать евразийское учение. Русский мир не мыслится без русского народа, но он также не мыслится и 
без других народов. Сегодня необходимо воссоединить духовные и материальные потенциалы России. От этого все народы выиграют и многое приобретут. Здесь огромное поле для совместной деятельности государственного аппарата, общественных формирований и церкви. Такие масштабные задачи должны решаться сообща, всем миром.

В основе преобразований русского мира должна лежать духовно-нравственная составляющая. Объединяющей общенациональной идентичностью должен выступать русский народ, а еще точнее - русский мир. Следовательно, надо все большее внимание уделять не проблемам русского народа, а проблемам русского мира, куда необходимо отнести язык, образование, науку, культуру, искусство, религию. Ядром здесь служит духовный мир русской культуры.

Важную роль играет здесь и опыт предшествующих поколений, в том числе и советский опыт национального и государственного строительства. Надо уметь изучать прошлый опыт. Тем более что в советский период нашей истории решению национального вопроса придавался 
фундаментальный характер. И в основе этого фундамента лежала русская духовная культура, национальная по форме и интернациональная по содержанию. Успешное решение проблем русского мира будет способствовать решению проблем России в целом. 


\section{СЛОВАРЬ КРИМИНАЛЬНОГО СЛЕНГА}

\section{A}

Автоматчик

«вор в законе», отслуживший в армии, тем самым, нарушивший воровское правило: из рук власти нельзя получать оружие.

Авторитет опытный

заслуживший преступной преступник, доверие в среде, пользующийся определённым влиянием и способный возглавить и руководить преступной группой.

Аристократ

Атас удираем, бежим.

Б

Бабки деньги.

Бабки

группировки. общаковые 
Бабло

деньги.

Баньки ставить избивать; вид наказания, применяемый согласно воровским понятиям.

Басило «вор в законе», имеющий власть над другими осуждёнными.

Бес осуждённый, хорошо работающий на предприятии.

Беспредельщики группа воров, отошедших от воровских традиций (в 40-е 50-е годы) и творящих беззаконие.

Блатная малина воровской притон.

Блатная музыка воровской жаргон.

Блядь агент, стукач, человек продажный, предающий интересы воровского мира.

Божиться давать воровскую клятву. Производное от призывания божественного имени при даче обещаний (клятв).

Болтать на фене владеть воровским жаргоном. 
Братва

Бродяги

Вешать лапшу врать.

Вор в законе приятели, товарищи.

общее название осуждённых.

B

принятый группировку, обязавшийся соблюдать воровские законы.

Вор списочный вор, принятый в группировку за какую-то услугу. Такой вор, за малейшую провинность, изгоняется из группировки.

Воровское поборы с осуждённых на нужды воров. благо

Выпрыгнуть уйти из воровской среды без разрешения, без честного отхода.

$\Gamma$

Гнилой опытный, знающй.

Голяк бедность, нищета (отсутствие денег, чифира и т.д.) 
Гопник

Грев

Дать по ушам

Два на три (шестёрка)

Дери-бери налётчик,

Поставить ограбить. (гопстопщник)

материальная поддержка вору или авторитету, попавшему сложное положение.

\section{Д}

обвинить

(разоблачить), изгнать из воровской среды.

человек, беспрекословно

выполняющий требования преступников. Мальчик на побегушках.

сформировавшаяся в 50-е годы, группировка осуждённых, близких по своей направленности к беспределу.

Дешёвый мир люди чуждые для преступной группировки.

Джабки

Дом отдыха печенье, пряники.

тюрьма, колония, место лишения свободы. Вероятно, от термина «дом заключения» 
(«домзак» - термин введён большевиками вместо слова тюрьма).

Домушник

Дорога

Егор

Ёрш

Жиган

Жить

положняком

Жулик

квартирный вор.

связь, по которой нелегально передаются запрещённые предметы и переписка.

E

вор, вызывающий поддержку у других воров.

вор, изгнанный из среды, но продолжающий выдавать себя за «вора в законе», там, где его не знают. Ёрш - вид отмычки или смесь из различных спиртных напитков.

$$
\text { Ж }
$$

преступник с солидным преступным прошлым. пользоваться авторитетом у осуждённых. авторитетный осуждённый. 
За атас

ежемесячные

вЗносы

порядочных осуждённых на организацию круглосуточных дежурств (стояние на атасе), за готовку порций в столовой, уборку и т.д.

Законник «вор в законе» - преступник, принятый в сходку, в воровскую группировку и обязавшийся выполнять традиции и обычаи воров, вор-хранитель традиций и обычаев преступного мира.

Запретка запретная зона, КСП (контрольно-следственная полоса), располагающаяся жилой зоной и основным забором, и также между живой и производственной зоной. Различают внутреннюю и внешнюю запретку.

Зарубка воровская клятва - «век свободы не видать», «зуб даю», «сука буду, если что», 
«легавый буду», «смерть легавым от ножа».

Зелёные

воровская

группировка (масть), возникшая в 40-х 50-х годах, не признающая никаких норм поведения.

Зона территория расположения учреждения, исполняющего наказание.

И

Иван

главарь преступной группы, камерный авторитет в царской тюрьме.

Игра на интерес игра на деньги (сигареты, чай, и т.д.). Часть выигрыша идёт на общак (в общий котёл). Играть можно не только в карты, но и в шахматы, домино и т.д.

K

Катала

мошенник, шулер.

Каторжанин осуждённый, отбывший длительный срок заключения. 
Катран

место в бараке (жилом помещении), оборудованное для игры в карты

Качать права разрешать на воровской сходке споры, доказывать правоту,

Кипешь (кипиш, хипиш - шум, драка, галдёж, своими корнями уходит в древней иврит, где хипиш - массовые беспорядки. Есть версия, что в основе лежит глагол кипеть (бурлить) - кипение, бунт, в частности, бунт осуждённых против администрации.

Кича (кичман) тюрьма, изолятор, карцер.

Князь вор-рецидивист, обладающий авторитетом.

Козёл доносчик, недруг, проданный, гомосексуалист (в пассивной форме). Так же имеет место прозвище «сапог», «велосипед», «мопед».

Козий барак место проживания осуждённых, занимающих 
должности, предложенные администрацией мест лишения свободы.

Коцы грубые рабочие ботинки.

Командировка отбывание срока наказания, а также, колония.

Красная шапочка сформировавшаяся в 40-х

годах

осуждённых группировка из бывших военнослужащих, не принятых ворами, бывший вор в законе, осужденный за мужеложство, пассивный гомосексуалист, член актива заключённых, демобилизованный ИЗ внутренних войск, милиционер.

Контора милиция.

Крытая (крышка) тюрьма.

Ксива (малява) записка, письмо, документ ксивуха.

Курва

\author{
человек, предающий воров, \\ проститутка.
}


Кудлатый

Кум

Леопард

Лепить

горбатого

Ломать

Лопатник

Ломом

путь

подпоясанный

Локальщик

Лохмач вор, имеющий грехи перед другими ворами.

оперативный сотрудник ОВД.

Л

опустившийся вор.

говорить несуразицу, чушь.

проверять, вытаскивать.

кошелёк.

осуждённый, вставший на исправления; не признающий авторитетов; недалёкий человек, рождённый для работы, мужик, простофиля.

открывающий и закрывающий калитку локальной зоны отряда. Крайне неуважаемая личность.

дружинник, член секции СВП (СПП). 
Люди

Майданник

Малина

Мандер

Маслина

Маслята пистолетные.

Мастер

Марочка

Медвежатник

Мокрушник

Мужик

воры в законе, соблюдающие свои обычаи, воры, все осуждённые.

\section{$\mathrm{M}$}

вор, промышляющий на железнодорожном транспорте. воровской притон. исполнитель воли авторитетов, посредник между вором и скупщиком, напарник шулера.

нож.

патроны, как правило, квалифицированный вор, пользующийся авторитетом среди преступников.

носовой платок.

взломщик сейфов.

убийца.

осуждённый, ничем себя не скомпрометировавший, 
выходящий на работу, поддерживающий общак, не сотрудничающий администрацией.

Музыка созревающая брага, поскольку шипит, бурлит, булькает, играет.

Музыкант владеющй воровским жаргоном.

\section{$\mathrm{H}$}

Нелепушник (самозванец), лицо, выдающее себя за вора в законе.

Ништяк (нищак) хорошо, здорово, приятно.

$\mathrm{O}$

Общак

воровская касса.

Общие дела действия, направленные на поддержание воровских традиций.

Одеть рога стать козлом, помощником администрации.

Окраска (масть) принадлежность определённой осуждённых.

\author{
$\mathbf{K}$ \\ категории \\ Опустить -
}


унизить, лишить арестантских прав, совершить насильственный акт мужеложства.

Отколоться

порвать

c воровской группировкой.

Отрицать

баланду

Оторваться

Оторва

Отдать

Пассажир

Пачуха

Пацан

отказываться от каторжной пищи.

получить наслаждение.

конченый, плохой человек.

оказать уважение.

предпочтение

\section{$\Pi$}

не принадлежащий к преступному миру, жертва в шулерской игре, просто знакомый человек.

пачка.

несовершеннолетний, поддерживающий близкие связи с ворами и обучающийся у них. 
Первая пятёрка

группа

наиболее авторитетных заключённых.

Перо

нож.

Подмолодить поколотить, избить.

Петушатник место проживания петухов, т.е. опущенных, обиженных и прочих самых презираемых категорий осуждённых.

Пехота

лица, не пользующиеся авторитетом среди отрицательно настроенной части осуждённых.

Поливать избивать, рассказывать небылицы.

Положняк осуждённый, занимающий видное положение B уголовной среде.

Получатель вор, совершающий, по решению сходки, акт наказания над другим вором, за нанесённое оскорбление (восстанавливает свою честь).

Понятия свод воровских правил. 
Полтинник

Поставить

Поставить

Правилка

Пресс

Пресс-хата

Пристяжь

Прокажённый

Прошляк

Пустить коня пятьдесят тысяч рублей.

прогнать из группировки. на лыжи

обворовать. Например, поставить квартиру.

самосуд осуждённых, суд воров. (правокачка)

давление, угнетение, стремление сломать личность.

камера с невыносимыми издевательствами.

лица, окружающие вора и оказывающие ему услуги.

опытный.

вор, ушедший из группировки добровольно.

передать записку из одной камеры в другую.

$\mathrm{P}$

Рамсы

правила, ориентиры. Попутать рамсы - ошибиться, напутать. Рамс - карточная игра. 
Рамки

Родич

Редиска

Свой в доску

Сесть на дно

Смотрящий

Столотёр

Твёрдый

Трюм

Трюмиловка

правила поведения лица из преступной среды.

опытный вор, обучающий несовершеннолетних.

нехороший человек.

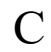

надёжный человек.

уйти из преступной среды, затаиться, затихнуть.

ответственный за соблюдение воровских традиций в камере, колонии, тюрьме, населённом пункте.

убирающий объедки со стола, презираемая личность.

$\mathrm{T}$

надёжный.

одиночная камера, штрафной изолятор.

насильственный

ритуал обращения вора или авторитета в сучью веру. 
Трюмить

морально или физически воздействовать на кого-либо, с целью заставить выполнить требуемое.

\section{$\mathrm{y}$}

Уйти налево

Утюг

Хата

Хиляем

Хитрый домик милиция. убийство.

$$
\mathrm{X}
$$

уходим.

изменить своей группировке.

вор в законе, совершивший

воровской притон, камера.

Ц

Центровой

преступник,

играющий главнейшую роль в группе.

Ч

Челюскин

бывший вор, нарушивший соблюдение воровских правил.

Чифир крутозаваренный чай. 
Чифирбак

приспособление для заварки чифира. Обычно консервная банка с проволочной ручкой.

Чистый авторитет у воров.

(честный)

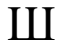

Шерсть

отрицательно настроенная часть осуждённых.

Шулерская притон азартных игр.

кильница<smiles>[AlH2]</smiles>

Щипач карманник. 
СЛОВАРЬ МОЛОДЕЖНЫХ СЛЕНГОВЫХ СЛОВ И ВЫРАЖЕНИЙ

A

Абитура

абитуриент, учащийся среднего учебного заведения, готовящийся к поступлению в вуз.

Агрегат

вещь любого типа.

Админ

сокр. от администратор.

Айда давай, пошли. Побуждение к какому-либо действию.

Айс хорошо.

Алкаш

человек

c алкогольной зависимостью.

Атас

предупреждение

об опасности.

Ата-та́

употребляется в значении секир-башка, капец, наказание.

Афигенски

здорово, хорошо.

Аффтар

автор

какого-либо

творческого произведения

Ахтунг

(от нем. achtung - внимание). 170 
1.Происшествие, чрезвычайное положение. 2. Недоумение, изумление. негативное 3.Состояние ужаса, неловкости.

Ацтой (отстой) ни о чем, неудачно, плохо.

Б

Ба́за репетиционная точка для музыкальных групп.

Бабахнуть выстрелить.

Бабкомёт банкомат.

Бабло, бабки, деньги. бабосы

Базар

разговор, беседа (отвечать за базар, фильтровать базар).

Базар держать отвечать за свои слова Базарить говорить, общаться. Как правило, произошло от слова "Базар" т.е. место, в котором большое скопление людей, общающихся друг с другом.

Балда бестолковый человек.

Балдеть веселиться. 
Баран

Барыга

Басня

неправда.

Батя

Башня, башка голова.

Баян

ББ (будь, будь) прощание.

Бегу и волосы отказ сделать что-нибудь в назад грубоватой форме (аналоги:

Без палева бегу в ритме вальса; лечу за вами, держите сзади; сейчас, шнурки поглажу и т.д.)

глупый

оскорбительный

отзыв, серьезность которого зависит от интонации говорящего. Упрек в упрямости и неуступчивости.

человек занимающийся куплей-продажей. Что-то покупает по одной цене, а продает с астрономическими накрутками. Наживаются на ажиотаже к тому, что продают.

сказка, выдумка, вранье, отец. старая шутка. незаметно, аккуратно. 
Безбашенный

Белка, белочка

Беспонто́во

Беспонто́вый

Блин

Бомбить

Борзометр

Борзый наглый.

Борода́ неуправляемый, непредсказуемый.

психоз, конкретнее, делирий, связанный со злоупотреблением алкоголя.

плохо, некачественно, невыгодно, неудачно.

плохой, некачественный, невыгодный, неудачный. Есть оттенок не оправдавшихся ожиданий, разочарования.

ругательство, более приличный заменитель нецензурного слова.

нервничать, злиться.

виртуальный прибор, показывающий степень наглости.

сильный, бесстрашный,

неудовлетворительный результат чего либо, шокирующее завершение какого-либо процесса.

Ботан (ботаник) ученик зацикленный на учебе, 173 
который не может прогулять предмет, и в основном говорит только об уроках.

Бро

(от англ. brother - брат). Лучший друг.

Бросить кости отправиться куда-либо, прогуляться.

Брутально что-то необычайно жестокое, но имеющее при этом некую эстетическую ценность.

Бугай страшный, большой человек.

Бутер бутерброд.

Буха́ть

употреблять спиртные напитки.

Бухло

общее название для любого спиртного напитка.

Быдло

(от пол. bydto - скот). Человек низкой духовной культуры, плохо воспитанный.

Быром

очень быстро.

Бычок

окурок.

Баян

повторение. 
В лифте

родиться

В пролете

Валить

Вáта

Варганить

Варежка

Взрывать мозг

Винда

Внатуре согласие.

не закрывать за собой дверь, например,

заходя в студенческую аудиторию последним. Повидимому, от того, что двери лифта закрываются автоматически.

человек, оставленный без надежды, обделенный; человек, у которого нет шансов; человек, упустивший какую-то возможность.

уходить.

глупость, выдумка, чушь.

что-то готовить, делать (например, сварганить ужин).

рот человека.

сообщать трудную для понимания и осмысления информацию, заставлять думать, ошеломлять.

операционная

система Windows.

подтверждение чего-либо, 
Влом, вломы

Вписка

Встрял

Втыкать осознавать.

Въехать

Вылупился

Выпасть в осадок

Вырубить

Газовать

Галимый

лень, не хочется.

квартира, где можно пожить или переночевать, зачастую в другом городе.

попал в неприятное положение.

понимать что-либо,

понять что-то, постигнуть смысл чего-либо.

пристально посмотрел.

быть крайне удивленным, озадаченным, ошарашенным, шокированным.

1. Выключить (об электроприборе, телефоне и т.п.). 2. Лишить сознания, способности к сопротивлению (в драке, спортивном поединке и т.п.).

\section{$\Gamma$}

жать на педаль «газа» в автомобиле.

плохой, отвратительный, 
немодный, не доставляющий никакого удовольствия

Геймер (от англ. game, gamer - игрок). Человек, увлекающийся компьютерными играми.

Гелик от «Гелендваген». Модель машины марки «МерседесБенц» .

Геморрой

проблема, неприятная, затянувшаяся ситуация.

Глумиться

веселиться, развлекаться, смеяться над чем-либо, кемлибо, дурачиться.

Глю́чить ошибочно оценивать визуальный объект.

Гнать 1. Говорить неправду, лгать, обманывать (аналог: гнать гусей, гнать тюльку). 2. Предъявлять претензии.

Голяк отсутствие чего-то.

Гон неправда, ложь, клевета, обман.

Гоу (от англ. to go - идти, ходить). Пошли, идем. 
Грамотный

Грузи́ть

Делать ноги

Дешманский

Диджей

Дикий

Догонять

Докопаться

Достать

До фени

ДР хорошего качества, хорошо сделанный; умный, стильный, модный; удачный.

напористо и упорно высказываться на тему, не интересующую слушателя, который тяготится разговором.<smiles>[Tl]</smiles>

уходить.

дешёвый.

(от англ. DJ, по первым буквам Disc Jockey). Ведущий музыкальной программы или радиопередачи, включающий звукозаписи, музыку.

странный.

понимать что-либо.

пристать к кому-то.

надоесть.

всё равно, неважно, наплевать, пофиг.

день рождения. 
Дрейфить

Дубак

Дурь

Жопа

Забить

Зависнуть

Загнаться

Зажигать

Закинуть удочку поинтересоваться, узнать, с просить.

Заколебаться

трусить.

холод.

наркотик.

\section{Ж}

затруднительное положение, обстоятельство неприятного характера, сложная, почти неразрешимая проблема.

\section{3}

1. Игнорировать, не обращать внимания, равнодушным. 2. Занять (место).

остаться в состоянии нереагирования ни на кого и ни на что.

задуматься над чем-то глобально или абсурдно.

отдыхать, веселиться.

устать от чего-либо быть физически, умственно. 
Закос

Закосить

Залететь

Заморочка

Замутить

Запилить

Запарить

Запороть

Зассать

Застукать

Заценить

Зачотный

Зомбоящик подражание кому- или чемулибо, создание видимости.

уклониться от обязанности.

забеременеть.

трудность,

трудно

понимаемая вещь, недоступная для понимания вещь.

придумать что-то, п риобрести, сделать.

вернуть все, как было, либо создать с нуля.

сильно надоесть.

испортить что-либо, напакостить.

испугаться, не решиться на какой-либо поступок.

застигнуть врасплох, застать на месте преступления.

посмотреть, оценить.

отличный, достойный похвалы.

телевизор. 
Зырить

смотреть, глядеть, рассматривать.

И

Иди в баню

предложение уйти, в грубой форме.

ИМХО

аббревиатура от англ. - In My Humble Opinion - «по моему скромному мнению».

Инет (сокр. от Интернет (от англ. Internet)). Мировая компьютерная сеть (англ. World Wide Web).

Инфа

сокращение от слова «информация» или личные данные, например в программе icq.

K

Каблук

мужчина-подкаблучник.

Казуал (кэжуал) (от англ. casual повседневный). Некто не имеющий индивидуальности, своего стиля, мнения и т.д., теряющийся в толпе на фоне остальных.

Кайф оценочная конструкция с 
общеположительным

значением.

Калдырь

веселый человек, который любит выпить или уйти в запой на некоторое время. Очень добрый и общительный.

Капец

Катать вату

Качать

Качок

Квасить

Кекс

Кинуть

Кинуть бомжа

Кипиш

выражение неудачи

заниматься чем-нибудь бесполезным.

переписывать с другого устройства или сети цифровые данные.

человек с сильно развитой (накаченной) мускулатурой.

употреблять алкогольные напитки.

человек, личность, индивид. обмануть, подставить.

сбросить вызов на мобильный телефон по принципу «Перезвони мне».

суета, беспорядок, волнение, паника. 
КК

Классуха

Клоун

Комильфо

Комп

Контакт

Кореш

Короед

Коры мочить

Корявки

Косарь

Косяк

Косячить конечно конечно.

классный руководитель.

клоунами называют людей, которые делают поступки, приводящие к ухудшению ситуации.

(от фр. kam il fou - красиво, благопристойно). Красиво, хорошо, отлично, круто.

сокр. от компьютер.

разговорное применение названия сайта vkontakte.ru.

приятель.

дачник в электричке, чаще всего как правило с хозяйственной тележкой и рюкзаком.

шутить шутки.

руки. Иногда ноги.

тысяча рублей.

ошибка, неверный поступок, проступок.

ошибаться. 
Копаться

Кошерять

Краб

Краля

Кранты

Кропаль

Крутбл

медленно

собираться, медлить, тянуть.

ругать, поучать, наставлять на путь истинный

1) Рука (при приветствии) молодёжный жаргон. 2) Крепление переднего нижнего рычага на ВАЗ 210809-99 - автомобильный жаргон.

красивая девушка, хорошо и дорого одетая.

плохое событие, нехорошее обстоятельство, проблемная ситуация, кажущаяся безвыходность положения.

очень мало, совсем немного, чуть чуть! Очень маленькая порция, чего-либо.

выражение своего восхищения чем-то, от соединения русского слова «круто» и английского суффикса «-able». Используется в телепередаче «Даешь молодежь!» 
Крыса

Ксерить

Ксива

Ky

Ку́льно

Куй

КЭП

Лавэ

Лагать человек, своровавший какойлибо предмет у своих.

делать копию при помощи копировального аппарата, делать ксерокопию.

какое-либо удостоверение. Например, удостоверение личности или права на вождение машины.

привет.

хорошо, неплохо.

Аналог созвучного нецензурного слова, обычно используемый для снижения степени нецензурности в контексте.

(от англ. Captain Obvious, Cap - Капитан очевидность). Человек, говорящий очевидные вещи, прописные истины.

Л

деньги.

медленно работать. 
Лажа

Лажать

Лалка

Ласты

Легавка

Лечить

Лимон

Линять
ошибка, ложь, что-то
низкокачественное, не выдерживающее никакой критики.

ошибаться, делать что-то низкокачественно.

девушка-неудачница.

ноги.

полиция (В 20-х гг. XX в. сотрудники полиции носили жетоны в форме головы охотничьей собаки, отсюда и название «легавый»).

словесно убеждать человека сделать что-то, чего он делать не хочет. Часто также используется в значении «говорить что-то, неприятное для восприятия или что-то, чего человек не хочет слушать».

миллион.

убегать, сбегать. Иногда используется в значении "уходить". Например, "он уже 
слинял" - он уже ушел.

Липа, липовый ненастоящий, фальшивый.

Ломаться

упрямиться, не соглашаться на что-то.

Лопатник

бумажник, портмоне.

Лол

аббревиатура английского выражения Laughing Out Loud - Я громко смеюсь. Слово lol эквивалентно нашему «ржунимагу».

Лузер

(от англ. loser - проигравший, неудачник; человек, часто проигрывающий).

Применяется не только по отношению к компьютерным играм, но и в более широком смысле слова "неудачник".

Ляс велосипед.

\section{M}

Магаз магазин.

Мажор богатый человек.

Маза толк, польза.

Мазать промахиваться. 
Мазила

человек, не обладающий меткостью.

Малина счастье.

Мармыга алкоголик.

Матюг мат, матерная ругань.

Махаться драться.

Махач, махалово драка.

Махнуться обменяться чем-либо.

Маячить мелькать перед глазами.

Мб сокр. от может быть.

Мейк-ап от англ. make up - макияж.

Мензурка стакан.

Мент

милиционер. Иногда

используется в отношении и других представителей власти. Не очень уважительное выражение.

Мерс, мерин Мерседес.

Месиво драка.

Мессага (от англ. message сообщение). Сообщение по SMS, электронной почте, на форуме в интернете или где188 
либо еще.

Метать

Мимо кассы

Мобила

Мозгодав

Мойдодыр

Мочить

Музло, музон

Мутить

Мутузить

Мухлевать

Мухлеж

Мыло кидать, бросать.

не по теме разговора, не вовремя.

мобильный телефон.

психиатр.

умывальник.

убивать.

музыка.

делать что-либо.

бить.

играть нечестно, не выполняя правил игры и пытаясь это скрыть.

нечестная игра, невыполнение правил игры.

1. Мыльная опера телевизионный сериал со слабым развитием сюжета, направленный на простое "убивание времени". 2. Электронная почта (от англ. $\boldsymbol{e}$ mail) 
Наворачивать быстро или с удовольствием есть (употреблять пищу).

Наворачиваться падать.

Нагревать обманывать.

Надыбывать (находить, наезд) Агрессивное давление на человека, обвинение его в чем-то, попытка заставить его сделать что-либо.

Нажираться напиваться.

Наезд агрессивное давление на человека.

Накалывать обманывать.

Налик наличные деньги.

Намыливаться собираться пойти куда-либо.

Напарываться натыкаться на что-либо.

Напряг проблема.

Напрягать волновать, доставлять беспокойство, оздавать напряжение.

Нарк, нарик наркоман.

Нарываться сознательно совершать какие190 
либо действия, которые заведомо ведут к неприятным последствиям или конфликту.

Нарыть найти.

Наяривать делать что-либо быстро, сноровисто.

Немеренно очень много.

Непонятка непонимание чего-либо (или в чем-либо), неразрешенный вопрос.

Непруха

невезение.

Нехай (от укр. нехай - пусть). Пускай. Например, "Нехай идет домой" - "Пускай идет домой".

Ник

прозвище, псевдоним. Чаще всего применяется B интернете.

Норм, нормуль хорошо, нормально.

Ноу-хау новинка.

Нуб новичок.

Ныкать прятать.

Нычка укромное место, куда можно 
что-либо надежно спрятать.

$\mathrm{O}$

Обламывать

мешать

осуществлению планов, иногда используется в значении "спускать с небес на землю".

Облом

неудача.

Обмывать

отмечать какое-то событие, выпивая алкогольные

напитки. Иногда употребляется в несколько искаженном смысле - просто отмечать, не обязательно выпивая.

Оболванивать стричь налысо.

Оборзеть обнаглеть.

Одиннадцатый пешком, на ногах.

маршрут

Огонь отлично, прекрасно.

$\mathrm{OK}$ (от англ. o’key, ok соглашение). Да, хорошо.

Окочуриваться умирать.

Опрокинуть выпить. 
Опускать

Остывать

Отвянь

Откорячка

Отмазка

Отрываться унижать.

успокаиваться.

отстань.

оправдание.

оправдание.

веселиться, удовольствие. получать

Оттопыриваться отдыхать, расслабляться.

Очко

Очковать

Очкоед

Палить

Параллельно

Параша

Парить

Париться

Пахать

Пепелац унитаз.

бояться, трусить. трус.

$\Pi$ засекать, смотреть. все равно. двойка (оценка в школах). Применяется в основном школьниками.

надоедать.

переживать.

усиленно работать, работать не покладая рук.

пепельница. 
Переться

Пикап

Пиндос

Пихать

Пичкать

Плюха

Погоняло, погремуха

Подрубать

Подсаживать

Пофигист

Ппц

Предки идти.

процесс знакомства с представителем

противоположного пола (чаще всего имеется в виду девушка).

американец.

продавать.

наполнять что-либо чем-либо. Часто используется

B несколько переносном смысле, например, накормить до отвала.

звонкий удар (чаще всего по лицу).

кличка, прозвище.

понимать.

Вводить кого-либо

B зависимость от чего-либо. человек, равнодушный к окружающему.

сокращенное «Пипец». родители. 
Прибамбас

современное и навороченное техническое устройство либо модная функция B техническом устройстве.

Прикид одежда, стиль одежды.

Прикидываться

одеваться.

Чаще всего используется в отношении модной одежды.

Прикол шутка.

Пробивать узнавать насчет чего-либо.

Прокачивать улучшать чего-либо.

Пролетать не получать того, что планировалось, ошибаться.

Пруха везение.

Пузырь бутылка.

Пшек издевательский синоним поляка.

$\mathrm{P}$

Развести

обмануть.

Разводить

совершение

определенных действий, направленных на получение чего-то от 
человека.

Рвать

побеждать.

Ржать

смеяться.

Ржач

смех или что-то очень смешное.

Репа

голова.

Родаки, родичи родители.

Рожа

лицо.

Рулез

(от англ. to rule - быть крутым) что-то очень хорошее, правильное.

Рулить

быть в чем-либо лучше других.

Рыпаться

пытаться произвести какоелибо агрессивное действие, физическое или просто конфликтное. В данном выражении подразумевается именно попытка, то есть также присутствует оттенок того, что действие не удалось.

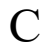

Сабы от фр. sous-titres - субтитры. 
Садить

Сачковать

Сачок

Свистеть

Сдувать

Сиги

Симка

Синий

Синька

Слива

Слизывать ухудшать состояние чеголибо. Используется как по отношению к внутренним органам, так и по отношению к предметам.

отлынивать от выполнения обязанностей.

человек, отлынивающий от выполнения своих обязанностей.

врать.

списывать.

сигареты.

SIM-карта

мобильного телефона.

человек, находящийся в состоянии алкогольного опьянения.

употребление алкогольных напитков B больших количествах.

(синяк) чаще всего имеются ввиду синяки под глазом.

списывать. Например, 
списывать

контрольную работу.

Слышь

послушай, слышишь.

Сморозить

сказать не в тему.

Смыться

уйти.

Совок

$\mathrm{Coю3}$

Советских

Социалистичеких Республик (CCCP). Чаще всего это выражение носит негативный и насмешливый оттенок.

Сошка человек, занимающий какоелибо значимое место в обществе или организации.

Старики родители.

Стеб смех, насмешка.

Стебаться смеяться над кем-либо.

Стопарь стакан.

Стопудово

непременно, обязательно, стопроцентно.

Стопэ погоди, остановись.

Стрелка разбирательство, сопровождаемой дракой.

Стремать используется в нескольких 


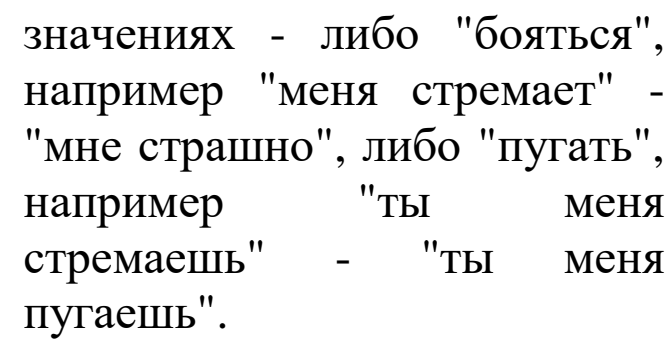

Стремно страшно (стыдно).

Студак, студень студенческий билет.

Стукач человек, который все время говорит то, чего нельзя рассказывать, тому, кому об этом нельзя знать. Произошло от слова "закладывать".

$\mathrm{T}$

Табло

лицо.

Тазик

спутниковая тарелка.

Тачка

автомашина.

Телик

телевизор.

Тёлка

девушка. В лучшем случае выражение имеет нейтральный оттенок, но чаще - пренебрежительное и унизительное отношение.

Тёрки конфликт, разбирательство. 
Терпила

Тикать

Тин (тинейджер) человек, который терпит.

убегать, сбегать.

(от англ. teenager подросток). Употребляется в основном самими тинейджерами, либо другими, достаточно молодыми людьми.

Толкать продавать.

Толчок

унитаз.

Тормоз

медленно соображающий человек.

Точить

Трабл

Трёп

Трепач

Трепаться

Трепло

есть какую-либо еду. Часто используется в виде "затачивать" - съедать.

(от англ. trouble - проблема, сложность). Проблема. пустой разговор, общение. Иногда имеется в виду просто разговор.

человек, не способный держать язык за зубами.

говорить не по важной теме.

болтун.

$$
200
$$


Трескать

Трещать

Троллить

Труба

Тусовка, туса

Тыква

Тырить

Убитый енот

Убогий

быстро или с удовольствием есть (употреблять пищу).

говорить без умолку.

хамить в Интернете.

мобильный телефон.

сборище людей, часто такое, где можно хорошо

повеселиться (дискотека, вечеринка). Так же иногда используется в значении "круг общения".

голова.

воровать.

\section{$\mathrm{y}$}

доллар. Произошло от общепринятой аббревиатуры у.е. (условные единицы), принятой для обозначения долларов, являющейся аббревиатурой и для слов "убитый енот". Используется в основном для юмористичности.

страшный. 
Угарать смеяться.

Угарный смешной.

Укурыш, укурок человек, регулярно злоупотребляющий курением марихуаны.

Усекать понимать.

Усыкаться смеяться.

Уши наушники.

\section{$\Phi$}

Фазенда дача.

Фейк (от англ. fake - ) Подделка.

Фейс лицо.

Фигня ерунда.

Филонить отлынивать от выполнения обязанностей.

Фингал, фонарь синяк. Чаще всего имеются в виду синяки под глазом.

Фифа

кокетливая девушка.

Фишка

изюминка, оригинальность.

Флудить

(от англ. to flood - ). Писать большое количество 
одинаковых сообщений или

почти

одинаковый

(в

компьютерной сети).

Форева

от англ. forever - навсегда.

Фортить

везти.

Фурычить

работать, нормально

функционировать.

Подразумевается какой-либо агрегат или механизм.

\section{$\mathrm{X}$}

Хавать

есть, употреблять в пищу.

Хавка, хавчик еда.

Xaep

(от англ. слова hair - волосы).

Прическа, волосы. Чаще всего применяется в отношении модной прически и т. п.

Xape

хватит.

Хана

большая проблема, «конец» (хана тебе).

Хата дом, квартира.

Ч

Чайник новичок, простак.

Чапать идти. 
Чел, чувак

молодой человек, мужчина. Чаще всего используется в довольно уважительном смысле.

Чердак, голова.

черепушка

Чесать врать.

Четырехглазый очкарик.

Чувиха девушка. Используется либо в нейтральном, либо B уважительном смысле.

Чума восклицание, обозначающее высшую степень восторга от чего-либо.

\section{Ш}

Шар

глаз.

Шарить

хорошо разбираться в чемлибо.

Шишка

человек, занимающий какоелибо значимое место в обществе или организации 
Шмон

Шмонать

Шпора

Штука

Штукатурка

Шухер

Юзаный

Юморить

смешное.

Я

Яга, яша

Ящик

обыск.

тысяча.

Ю (от др. евр. - восемь)

шпаргалка.

косметика.

предупреждение

об

опасности.

(от англ. слова to use использовать). Бывший в употреблении, подержанный, потерявший товарный вид.

шутить, делать что-то

Слабоалкогольный сладкий энергетический коктейль «Ягуар».

Телевизор. 
СПИСОК ЛИТЕРАТУРЫ:

1. Амбарцуев И.В. Тайная история нового французского двора / образ Наполеона I в русской официальной пропаганде, публицистике и обобщённом сознании в XIX веке/ И.В. Амбарцуев образ Наполеона I в русской официальной пропаганде, публицистике и обобщённом сознании в XIX веке http://www.museum.ru/1812/librari/parthor.h tml

2. Багаутдинов А.А. Язык, как метаконцепт и конструктор социокультурной реальности / А.А. Багаутдинов язык, как метаконцепт и конструктор социокультурной реальности - Воронеж, ВГПУ. 2010 - с. 6-11.

3. Там же - с. 19

4. Бибихин В.В. Язык философии/В.В. Бибихин язык философии. М., -1993. -c5.

5. Библия. Новый завет. Евангелие от Иоанна/Евангелие от Иоанна. Новый завет. Библия. М. Российское библейское общество $1993-$ с.895.

6. Там же Бытие 1,27. 
7. Там же послание к Римлянам святого Апостола Павла 10, 17.

8. Бушуев А.Б. Культура философского мышления и языковая личность/А.Б. Бушуев Культура философского мышления и языковая личность/ Шестой международный культурологический философскоконгресс/ http://www.humanites/ru/db

9. Бьюкенен Дж. Сумерки богов или смерть Запада/Дж Бьюкенен Сумерки богов или смерть Запада. М, -2001. - с. 156

10. Вежбицкая А. Семантические универсалии и описание языка/ A. Вежбицкая Семантические универсалии и описание языка - М., 1999. -c.293.

11. Даллес А. Размышления о реализации американской послевоенной доктрины против СССР 1945/A. Даллес Размышления о реализации американской послевоенной доктрины против СССР 1945 // www/zapret.narod.ru

12. Ирзабеков $Ф$ тайна русского слова/Ф Ирзабеков тайна русского слова - М., 2010. - C. 17-18. 
13. Там же с.37

14. Колеман Джон Комитет 300 / Джон Колеман Washington. -2002 c.177.

15. Коростовцев
египетскую
филологию/ Введение в Коростовцев Введение в египетскую филологию - М., 1963. - С. 31.

16. Лосев А.Ф. философия имени/ А.Ф. Лосев философия имени. М., 1999. c.127.

17. Риккер П. конфликт интерпретаций: очерки о герменевтике/ П. Риккер конфликт интерпретаций: очерки о герменевтике. М., 1995. - с. 14.

18. Резолюция XI Всемирного Русского Народного Собора. Москва. 2012г./Материалы XI Всемирного Русского Народного Собора. - М., -2012.

19. Свирелин А. Этимологический словарь в 4-х томах/М. Фасмер - М., 2004 - с. 550551. Полный церковно-славянский словарь для чтения/Г. Дьячко - М., 1900. С. 849/ А. Свирелин Полный церковнославянский словарь для чтения. - М., 1963 -c. 31 . 
20. Свириденко А.А. Русская культура и отечественная школа/А.А. Свириденко Русская культура и отечественная школа. 